dossiê: imagens da moda e do vestuário ]

[JAQUELINE MORAES DE ALMEIDA]

Mestra e doutoranda em História pela Unicamp (SP) e docente do

departamento de História do Colégio Dante Alighieri

jaquelinemoraesalmeida@gmail.com

\title{
Modas de madames e mocinhas: a colaboração de Alceu Penna em A Cigarra Magazine
}

Fashions of ladies and girls: Alceu Penna's collaborations in A Cigarra Magazine

\begin{abstract}
[resumo] As trajetórias de A Cigarra (1914-1975) e Alceu Penna (1915-1980) estão muito entrelaçadas. Integrada aos Diários Associados de Chateaubriand em meados da década de 1930, a revista passou a contar com as colaborações do artista gráfico e figurinista mineiro nessa mesma época. Com as jornalistas Helena Ferraz e Elza Marzullo, desenvolveu A Cigarra Feminina, um amplo suplemento da revista que circulou entre 1948 e 1955. Utilizando o gênero como categoria de análise histórica, e ainda como maneira de observar as relações de poder, pretendo, neste artigo, relacionar os trabalhos de Penna com a produção de normativas, bem como sugeridas às leitoras, explicitamente ou nas entrelinhas e nos entretraços. Para tanto, farei uma análise imagética e textual da fonte selecionada.
\end{abstract}

\section{palavras-chave}

Alceu Penna; A Cigarra; moda; normatividade; mulheres jornalistas.

[abstract] he trajectories of A Cigarra and Alceu Penna are very close. Integrated into the Diórios Associados of Chateaubriand in the mid of 30's, the magazine received the collaborations of graphic artist and costume designer born in Minas Gerais. With the journalists Helena Ferraz and Elza Marzullo, he developed A Cigarra Feminina, a wide internal supplement to the magazine, that circulated between 1948 and 1955. From genre studies, and characterizing it as a way to observe power relations, I intend in this article to relate Penna jobs and the production of normatives and on the other hand, the counter-conducts suggested to female readers, explicitly or between the lines and entretraços. Therefore, I will make an imagistic and textual analysis of the selected source.

[keywords] Alceu Penna; A Cigarra; fashion; normatives; women journalists 


\section{A Cigarra e Alceu Penna}

No ano de 1915, em Curvelo, pequena cidade localizada no centro do Estado de Minas Gerais, nasceu Alceu de Paula Penna, filho de Christiano Penna e Mercedes de Paula. Meses antes, em março de 1914, uma nova revista de variedades começou a circular em algumas cidades do Brasil: A Cigarra, fundada em São Paulo pelo jornalista Gelásio Pimenta (1879-1924). Ao custo de 400 réis, o primeiro número anunciou:

A grande ambição da Cigarra é ser uma revista artística: cantar ao sol com voz que se esforçará - ou não fosse ella cigarra - por fazer alta e estridente. É a sua ambição: não é uma promessa. Prometer obriga; e quem sensatamente se obrigará pelo seu próprio destino? ${ }^{2}$

Com redação e administração localizadas em um prédio na Rua Direita, a publicação, a princípio quinzenal, apresentava uma série de fatos e fotografias relacionados à vida social da capital e de algumas cidades do interior do Estado de São Paulo. Além disso, estampavam suas páginas: contos, poesias, concursos culturais, modas, esportes e outros assuntos que interessavam aos leitores/consumidores daquele momento. Apesar de classificada enquanto revista de variedades, $A$ Cigarra sempre privilegiou os conteúdos associados aos interesses femininos (CRUZ, 1997).

Depois da morte do fundador, em 1926, Paulo Pinto de Carvalho assumiu o cargo de diretor da publicação e manteve, até meados do início da década de 1930, as principais caracteristicas de A Cigarra, como o apego ao público paulistano e a periodicidade quinzenal. Entretanto, não levaria muito tempo para que Assis Chateaubriand (1892-1968) incorporasse a revista ao domínio dos Diórios Associados, que, desde 1928, já contava com a semanal ilustrada 0 Cruzeiro.

\section{No começo daquele ano [1933] ele [Chateaubriand] decidira dar outra finalidade ao dinheiro que arranjara com Samuel Ribeiro e Martinelli a pretexto de importar os transmissores de rádio: com- prou a revista $A$ Cigarra (...). Entregou a direção da nova publicação ao poeta paulista Menotti Del Picchia e transformou-a em uma revista de circulação nacional. (MORAIS, 1994, p. 320)}

A incorporação da revista aos Diários aconteceu aos poucos. Seu caráter paulista, por exemplo, foi preservado por intermédio da direção de Menotti Del Picchia (1892-1988). Apesar disso, e da permanência da sede da redação em São Paulo, alguns colaboradores de $O$ Cruzeiro (muitos deles do Rio de Janeiro) passaram a enviar trabalhos para a nova magazine de Chatô. As transformações que cercaram A Cigarra, e, sobretudo, o momento em que elas ocorreram, propiciaram mudanças na trajetória de Alceu Penna.

No início de 1932, o Jornal do Brasil divulgou diversas notas relacionadas ao exame vestibular da Escola Nacional de Belas Artes, e foi assim que o nome do curvelano começou a aparecer nos veículos impressos da então capital nacional. De acordo com o biógrafo Gonçalo Junior, Alceu iniciou sua carreira como ilustrador já em 1933, publicando desenhos no Suplemento Infantil, de 0 Jornal, periódico dos Diários Associados (JUNIOR, 2011). Uma vez inserido no grande empreendimento de Chateaubriand, as possibilidades de fazer carreira em publicações de grande circulação aumentaram: meses depois, suas ilustrações tomaram páginas e capas de 0 Cruzeiro.

Já com periodicidade mensal, o número de $A$ Cigarra publicado em junho de 1934 explicitou as principais transformações ocorridas na estrutura da revista: a começar pelo novo título, A Cigarra Magazine e a ampliação do número de páginas (algumas em papel couché), além da inserção de diversas ilustrações. 


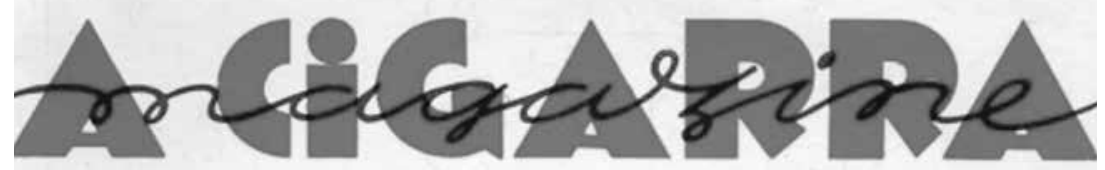

to Paule JUNHo DE 1934 Me de Jane

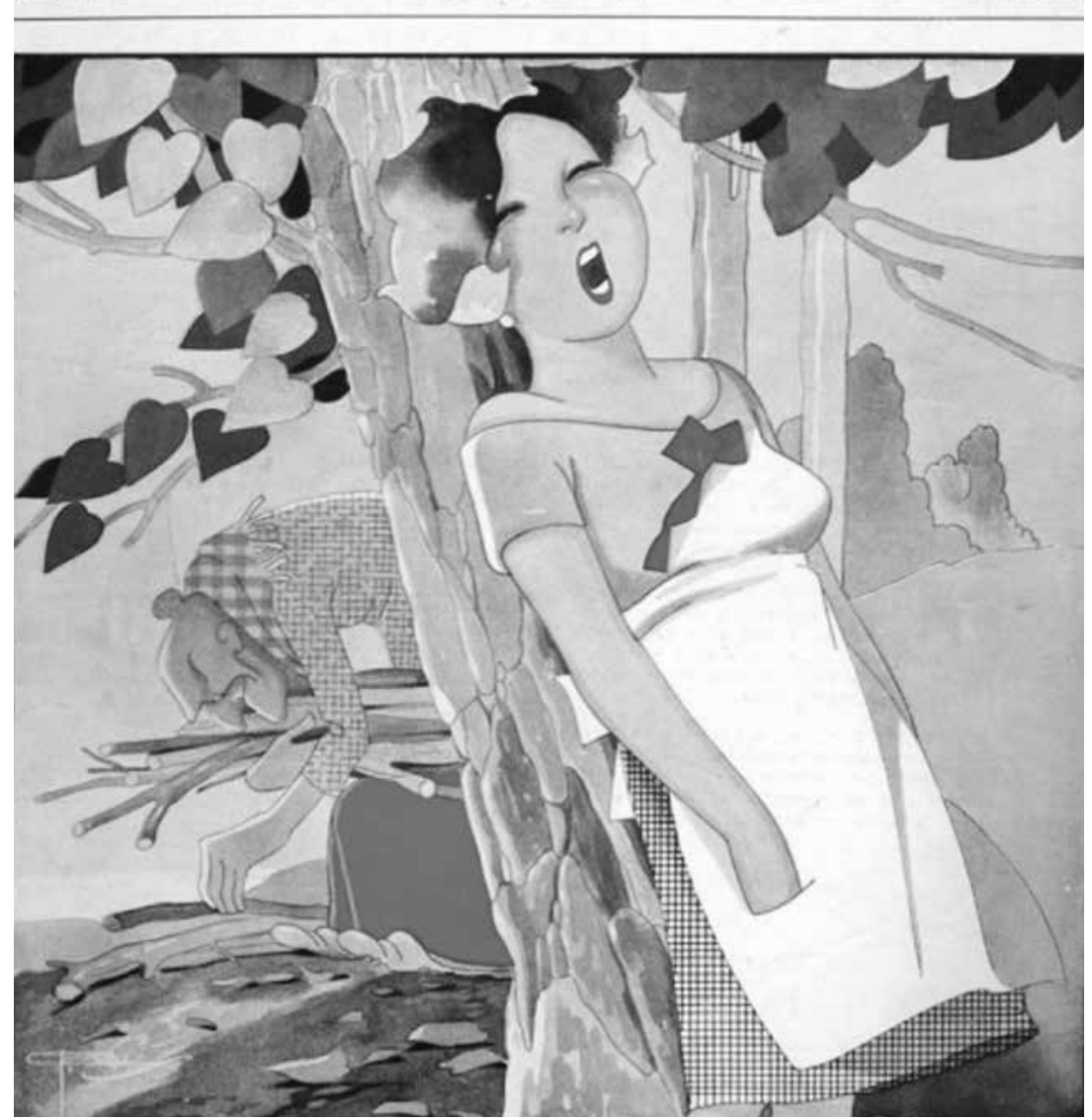

Figura 1 - Capa de A Cigarra ilustrada por J. Carlos. Fonte: A Cigarra, ano XX, n. 3, junho de 1934, p. 93. Acervo: Arquivo Público do Estado de São Paulo (Apesp).

A partir dessas mudanças, e tendo em vista a colaboração de diversos escritores e artistas gráficos de $O$ Cruzeiro no desenvolvimento da nova fase de $A C i$ garra, a autoria da capa do número de junho de 1934 poderia estar relacionada à figura de Alceu. No entanto, a assinatura de um artista, presente no canto inferior esquerdo da capa, confirma que os olhos cerrados e o rosto arredondado da personagem em evidência foram, na verdade, elaborados pelo carioca José Carlos Brito, mais conhecido por J. Carlos, um dos ilustradores mais importantes da primeira metade do século XX, colaborador em diversos impressos nacionais de elevada tiragem e circulação, tais como O Malho, Careta, Fon-Fon! e 0 Cruzeiro (LUSTOSA apud LOPES, PESAVENTO; VELLOSO, 2006). Sobre as semelhanças constatadas nos traços dos dois artistas, Gabriela Penna escreveu:

Percebem-se influências de J. Carlos nos desenhos do ilustrador [Alceu], mais precisamente, no início de sua carreira na década de 1930. A forma do rosto arredondada, as sobrancelhas finas, os olhos ligeiramente puxados e a boca pequena são traços percebidos nas figuras femininas de J. Carlos e de Alceu Penna. (PENNA, 2010, pp. 22-3) 
As ilustrações de Alceu para o romance policial de Christian Haugen 0 documento mysterioso - que marcam o início das atividades do artista mineiro em A Cigarra, também no número de junho de 1934 - evidenciam as semelhanças comentadas.

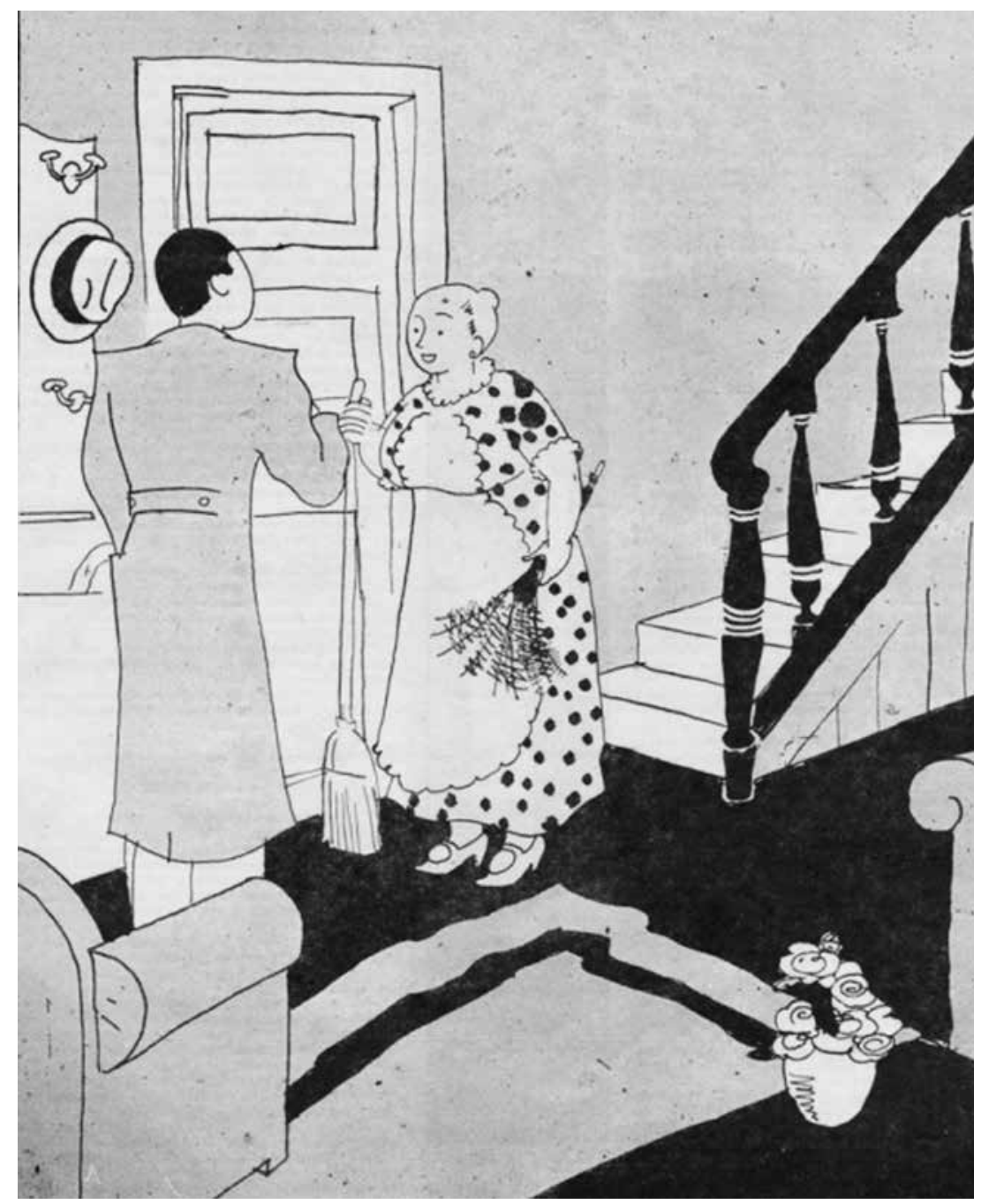

Figura 2 - Ilustração de Alceu para o romance policial de Haugen. Fonte: A Cigarra, ano XX, n. 3, junho de 1934, capa. Acervo: Apesp.

Ainda que tenha sido uma espécie de freelancer nos Diários Associados, o trabalho de Alceu em A Cigarra perdurou por anos, mais especificamente, até meados da década de 1960. Ainda nos anos 1930, ilustrou algumas capas da revista; nos 1940, ao lado da cronista Marion (da qual tratarei mais adiante), assumiu as ilustrações do Suplemento Feminino; depois, no fim da mesma década, foi responsável por uma seção de figurino em A Cigarra Feminina, trabalhando ao lado de Elza Marzullo (?-1997) e da jornalista Helena Ferraz de Abreu (1906-1979).

\section{Encontros e trajetórias: Alceu, Helena e Elza}

A Cigarra Feminina, como o próprio nome sugere, foi um amplo suplemento dirigido às leitoras de $A$ Cigarra. Idealizado pela escritora e jornalista Helena Ferraz de Abreu, foi lançado no mensário em junho de 1948. Em uma 
entrevista ao jornal Diário da Noite, dos Diários Associados (Rio de Janeiro, 10 de junho de 1948), Helena destacou as colaborações de Alceu Penna e Elza Marzullo no caderno: "Como colaboradores o suplemento tem os nomes de Elza Marzullo [antiga apresentadora do programa Detalhes de elegância e beleza, na Rádio Tupi] e Alceu Penna. Elza ampliará a sua secção de Beleza, dando também conselhos sobre educação física; Alceu continuará a apresentar interessantes modelos com seu traço inimitável".

A seguir, então, como as trajetórias dessas três pessoas foram interceptadas e como, individual ou coletivamente, contribuíram para a formação e a divulgação de determinadas imagens e possibilidades relacionadas às mulheres.

Helena Ferraz de Abreu nasceu em 1906, no Rio de Janeiro; era filha de Maria Olympia Pitanga e do poeta parnasiano Bastos Tigre (1882-1957). Por meio de seu necrológio, produzido por ela mesma às vésperas de sua morte e publicado no jornal 0 Globo (13 de dezembro de 1979, p. 18), sabe-se que iniciou sua carreira como escritora aos 8 anos de idade, colaborando no jornal manuscrito 0 Potoka. Na década de 1930, fundou com o marido, Mauricio Ferraz, o suplemento Correio Universal. Sobre o empreendimento, Arnaldo Ferraz de Abreu, segundo filho do casal, declarou: "Papai tinha um suplemento distribuido gratuitamente junto com os jornais de grande circulação no país nas décadas de 30 e 40 . Só ganhava na publicidade. 0 nome era pretensioso: "Correio Universal", mas era "feito em casa", pelo casal. Além dos versos de Bastos Tigre e Álvaro Armando (pseudônimo masculino utilizado por Helena) e das seções sobre artesanato e culinária, o suplemento investiu na divulgação de histórias em quadrinhos (HOs) estrangeiras e nacionais. Em 1944, a mando do Departamento de Imprensa e Propaganda (DIP), o Correio Universal deixou de circular.

Ainda de acordo com o necrológio, Helena teria passado para 0 Globo Juvenil - publicação infanto-juvenil lançada por Roberto Marinho em junho de 1937

o licenciamento das seguintes HOs: 0 Fantasma, Século XXX e Brick Bradford (estrangeiras), além das nacionais Guarani e João Timbira, ambas ilustradas por Francisco Acquarone (1898-1954). É provável que Alceu, verdadeiro apreciador de histórias em quadrinhos, já tivesse conhecimento do trabalho de Helena, principalmente daquele relacionado ao Correio Universal; no entanto, a relação entre ambos deve ter se consolidado a partir da colaboração do ilustrador no Globo Juvenil (JUNIOR, 2004).

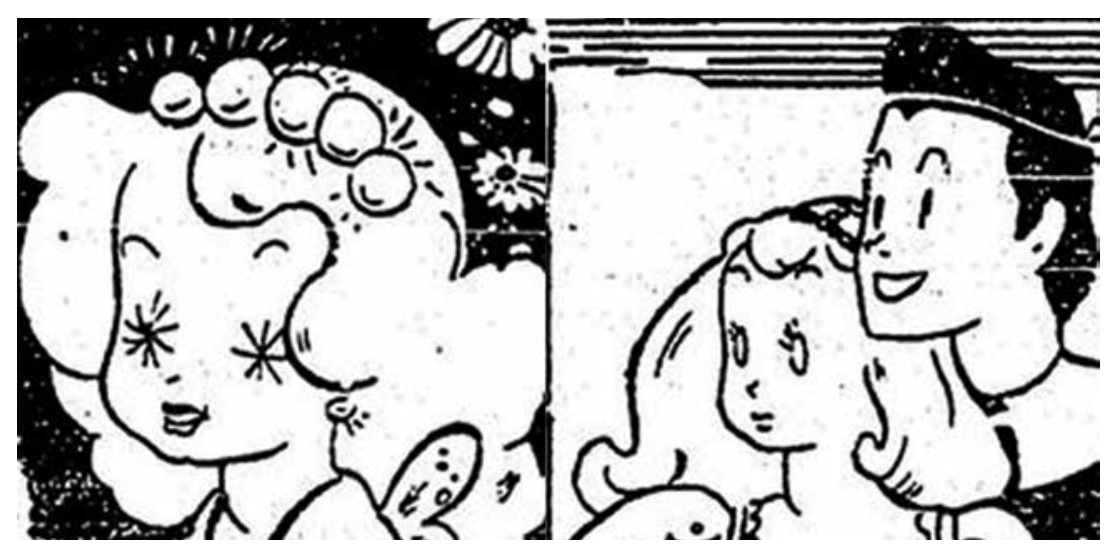

Figura 3 - Ilustrações de Alceu para a HO Sonho de uma noite de verão. Nesse período, início da carreira do ilustrador, os olhos em formato de asterisco eram uma das caracteristicas de seus desenhos. Fonte: 0 Globo, 24 de setembro de 1937. Acervo: 0 Globo.

Apesar de muito ligada à imprensa feminina, Helena Ferraz participou de outros projetos, alguns deles, inclusive, bastante ousados para a época. Sua própria trajetória pessoal e o pseudônimo masculino permitiram que ela fosse além da 
construção e da divulgação de poemas líricos e textos didáticos direcionados às mulheres. Em 1947, por exemplo, publicou Na berlinda, uma coletânea de sonetos satíricos dedicados às principais figuras públicas do periodo, como Getúlio Vargas, Carmen Miranda e Carlos Lacerda, entre outros. Em 1964, foi eleita diretora da Associação Brasileira de Imprensa, cargo nunca antes ocupado por uma mulher.

Em 1939, na Tupi (emissora de rádio dos Diários Associados), o programa Detalhes de elegância e beleza, patrocinado por Leite de Rosas, era comandado pela jovem Elza Marzullo. Algum tempo depois, durante a década de 1940, Elza e Maria Teresa - pseudônimo feminino utilizado por Accioly Netto, diretor de redação dos Diários - pilotaram as seções femininas da revista 0 Cruzeiro, que, nesse momento, projetava direcionar-se com mais ênfase às leitoras; prova disso são a criação e o desenvolvimento da coluna Garotas do Alceu, um dos trabalhos mais lembrados e reconhecidos de Alceu Penna. Ao contrário de Helena Ferraz, "imortalizada" em razão de seu próprio esforço de escrita, não existem muitas evidências sobre a vida pessoal e profissional de Marzullo. Segundo um impresso da Academia Brasileira de Moda, do Instituto Zuzu Angel, ela teria sido pioneira no jornalismo de moda no Brasil, "fundando o primeiro caderno feminino da nossa imprensa, no 0 Jornal, na década de 40" (Acervo pessoal de Celina de Farias).

Em Modernidade periférica, Beatriz Sarlo descreveu e problematizou os percursos biográficos das escritoras argentinas Norah Lange, Alfonsina Storni e Victoria Ocampo. Para iniciar a discussão recuperou Sylvia Molloy, quando esta mencionara as possiveis categorias de escrita durante as primeiras décadas do século passado destinadas às mulheres: a poesia e os textos educativos. Nesse sentido, Sarlo sustentou que: "Apesar de já ser admissivel que as mulheres escrevam, elas devem fazê-lo como mulheres, ou melhor, destacando que, ao escrever, não contradizem a caracteristica básica de seu sexo. 0 homem é cultura, a mulher natureza" (2010, p. 130).

Organizadora de uma coletânea de poesias, Antologia das rosas (1948), e autora de um manual de beleza e comportamento, Detalhes de elegância e beleza (1948), Elza Marzullo consolidou seu nome a partir de publicações voltadas essencialmente ao público feminino. Por isso, apesar de ter a escrita como instrumento de sustento e diferenciação social, seu exercício ficou restrito às categorias consideradas como próprias e ideais à mulher escritora: escreveu poesias e textos educativos.

\section{O Suplemento Feminino}

Durante a primeira metade do século XX, diversas publicações femininas foram fundadas no Brasil, como o Jornal das Moças e a Revista Feminina, ambas lançadas em 1914. Também durante esse periodo, algumas revistas de variedades passaram a investir em grandes seções dirigidas essencialmente às mulheres, como é o caso de $A$ Cigarra.

Em janeiro de 1937, por exemplo, o Suplemento Feminino - então entendido como uma das categorias do índice de $A$ Cigarra, e não como uma espécie de caderno ou grande seção da revista, responsável por integrar todos os assuntos femininos $^{3}$ - era constituído basicamente por conteúdos relacionados à moda internacional, enviados por correspondente ou simplesmente comprados pela publicação. As 15 páginas (aproximadamente) apresentavam diversas ilustrações em preto e branco, acompanhadas de pequenos textos, discretas propagandas e uma única fotografia. Na maioria das vezes, o conteúdo textual e as imagens expostas não apresentavam qualquer tipo de relação. Em agosto do mesmo ano, outros 
assuntos passaram a compor a lista de "efemeridades femininas", como receitas culinárias e dicas de beleza. Essa nova diagramação foi razoavelmente preservada até 0 fim da década.

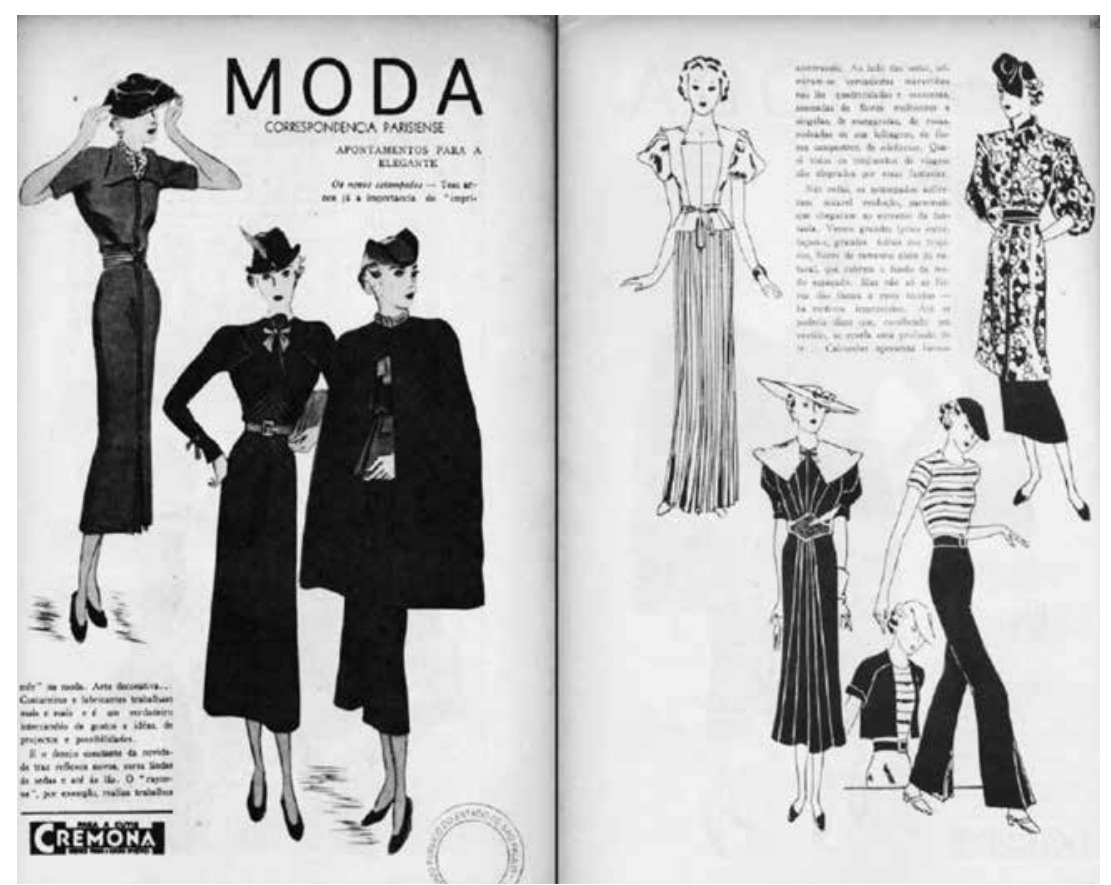

Figura 4 - As duas primeiras páginas da seção de moda, correspondência de Paris. Fonte: $A$ Cigarra, ano XXII, n. 34, janeiro de 1937, pp. 101-102. Acervo: Apesp.

Certamente a seção de moda de A Cigarra sempre esteve aos cuidados de alguém, fosse um diretor colaborador ou uma pessoa incumbida de adquirir imagens e textos de outros meios. Mas apenas em 1940, esse sujeito foi revelado ao público: Marion - seu primeiro nome, feminino e de origem francesa, é tudo o que temos. É difícil, então, saber se se trata de uma correspondente internacional, por exemplo, ou de alguém da própria redação da revista, homem ou mulher (BONADIO; BOAVENTURA, 2013).

Nos segmentos que tratavam de moda, a presença de nomes femininos e de origem francesa era recorrente. Na Revista Feminina (1915-1936), Marinette era responsável pela coluna fixa $A$ moda. Em $O$ Cruzeiro, Dona, uma seção fixa lançada em 1929, levava a assinatura de Madame Clemenceau. De fato, em um momento em que Paris se mantinha como capital criadora e difusora da moda, nada parecia mais eficaz e coerente do que conceder a responsabilidade de um segmento de moda a uma francesa - ainda que essa identidade não fosse verdadeira. E "francesa", porque sendo ou aparentando ser uma mulher, a colunista teria ainda mais propriedade para falar sobre assuntos femininos. Assim, as revistas se mostravam atentas às demandas de seus públicos, contratando correspondentes internacionais, adquirindo materiais do estrangeiro e/ou inventando identidades.

A seção de Marion ainda era composta por, aproximadamente, 15 páginas que costumavam ser ocupadas por crônicas, receitas culinárias, dicas de beleza e comportamento, poesias e diversas ilustrações de moda. Os croquis e 0 espaço total que ocupavam no Suplemento Feminino remetiam àquela estrutura anterior, da década de 1930. Além disso, imagens e textos continuavam autônomos, isto é, na maioria das vezes não havia qualquer ligação entre os seus conteúdos. 


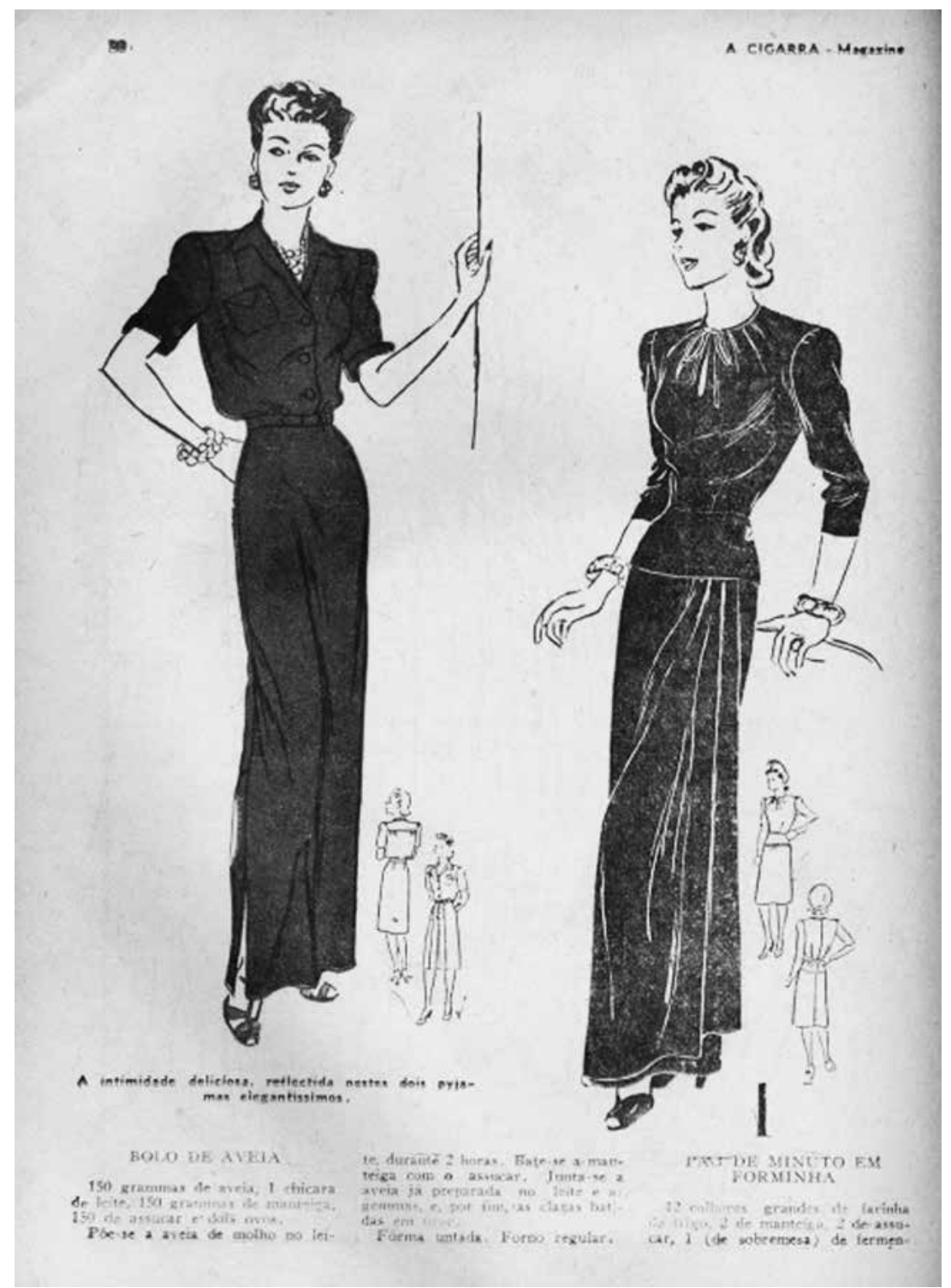

Figura 5 - Desenhos de moda dividiam espaços com receitas culinárias. Fonte: A Cigarra, ano XIX, n. 81, dezembro de 1940, p. 80. Acervo: Apesp.

A escolha dos desenhos em detrimento das fotografias de moda pode ser sugerida por meio do seguinte trecho, também publicado no número de dezembro de 1940, de A Cigarra: "Oferecemos, nas páginas que acompanham esta crônica, às nossas gentis leitoras, as últimas criações da alta costura que Hollywood nos envia enquanto Paris continua entristecida sob o cativeiro inclemente". Além de desestabilizar o calendário e a produção de moda, a ocupação alemã, em Paris, interferiu na maneira como o sistema da alta-costura se relacionava com os agentes de moda - jornalistas e copiadores, por exemplo. Na própria imprensa francesa, a frequência dos "ecos da haute couture" foi bastante afetada e reduzida, principalmente a partir de meados de 1943. Ademais, os figurinos deixaram de ser reproduzidos por meio de recursos fotográficos (VEILLON, 2004, p. 194). Ora, se internamente o contato relacionado 
às produções das maisons fora dificultado, nos demais paises - especialmente nos mais afastados daquele polo - tal acesso se tornou praticamente inviável. Esse, então, foi um dos motivos responsáveis por impulsionar as publicações interessadas no assunto a deslocar seus investimentos para outros "lugares da moda", como Hollywood e Nova York (HAYE; MENDES, 2003, p. 102).

Coincidentemente, de 1939 a janeiro de 1941, Alceu Penna esteve fora do Brasil. Depois de lançar Garotas, em 0 Cruzeiro, resolveu partir para os Estados Unidos - um projeto pessoal, anterior ao desenvolvimento da coluna (JUNIOR, 2011). Para não perder o vínculo com os Diários Associados, firmou um compromisso com Accioly Netto, assumindo um cargo com valor similar ao de um correspondente internacional. Lá, em 1939, trabalhou com Lúcio Costa e Oscar Niemeyer no estande brasileiro da Feira Mundial de Nova York. Além disso, de acordo com Gonçalo Junior, acompanhou de perto a turnê de Carmen Miranda, atuando como consultor informal da cantora e do Bando da Lua (2011); e foi o primeiro cartunista brasileiro a publicar na Esquire Magazine, revista especializada no público masculino ${ }^{4}$.

Em meados de 1940, Alceu retornou ao Brasil e algum tempo depois, em 1944, assumiu todas as ilustrações do Suplemento Feminino de Marion, em $A$ Cigarra. Por meio de uma breve análise, e comparando os desenhos do artista gráfico para a seção com os anteriores ali divulgados, há de se notar pelo menos duas alterações: uma relacionada ao uso das cores e outra associada ao traço. Os desenhos sem autoria eram preenchidos apenas com cores primárias (vermelho, azul e amarelo); Alceu aplicou novas cores e tonalidades em suas criações. Além de potencializar os croquis de moda, todo esse colorido foi capaz de diferenciar o suplemento dos demais segmentos da revista. Quanto aos traços, por mais que o enfoque principal do desenho continuasse a ser a vestimenta, 0 artista não perdeu a oportunidade de também investir nas modelos de papel, acrescentando-Ihes expressões faciais e poses diversas. Ele inovou, ainda, ao criar cenários, como o da figura a seguir.

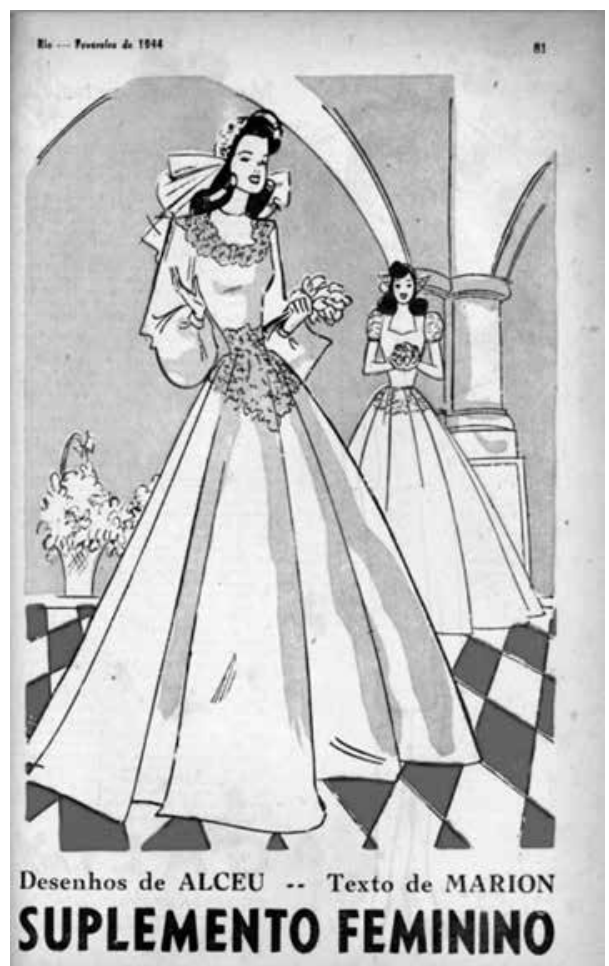

Figura 6 - Capa do Suplemento Feminino, com desenhos de Alceu Penna e textos de Marion. Fonte: A Cigarra, ano XXIV, n. 119, fevereiro de 1944, p. 81. Acervo: Apesp. 
A partir de novembro de 1945, a direção do Suplemento Feminino foi entregue a Elza Marzullo, já habituada a organizar e a transmitir elementos considerados como do interesse feminino. A partir disso, praticamente toda a estrutura do segmento foi alterada: a maioria das ilustrações relacionadas às tendências de moda foi substituída por fotografias e o conteúdo textual - inclusive aquele conectado às imagens de modelos (looks) - foi visivelmente ampliado e elaborado de forma a criar uma ideia de proximidade entre Elza e suas leitoras. Além do mais, nesse suplemento, elementos da cultura norte-americana foram intensamente referendados, principalmente as vestimentas, os cabelos, os corpos e as atitudes femininas, exemplificados pelas atrizes de Hollywood.

\section{Ultima moda esportiva}

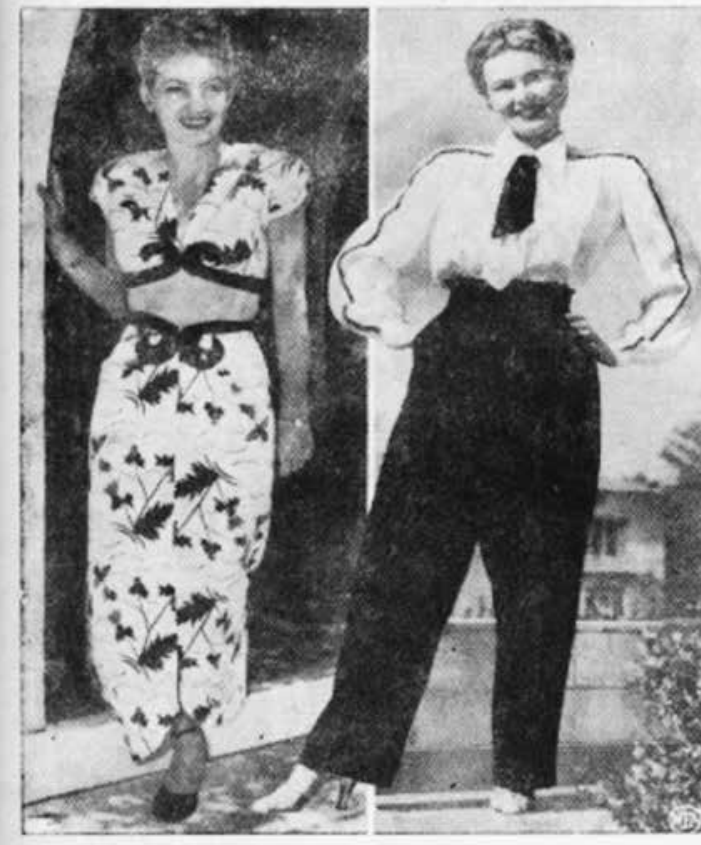

Menos nudismo - é a nota dominante nas criações que vêm da Califórnia

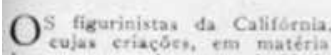
it esporte, sanham poptlariated noestrar, mesmo durante as res. tricjes impostas pela kuerra, que.
por meio do detallhe, podiam arr

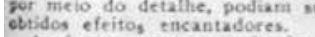
Aqui temos, por exempla, tiste: atuais - sugetrivos. Bles nos pa. recem mesmo criasoes de muito

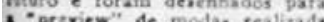

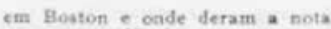
Cor sua tendencia deram a nots fismo en materia de praia.

Além das elegantes roupas de oxpho com que os derenhistas da cainortia embetezam 25 prans in exposicio de Povion Anseles. tambem os treics gue poderso inpirar at cariocas neste mo. cento peniando na elexaticia Copacabana nos próximos dias de

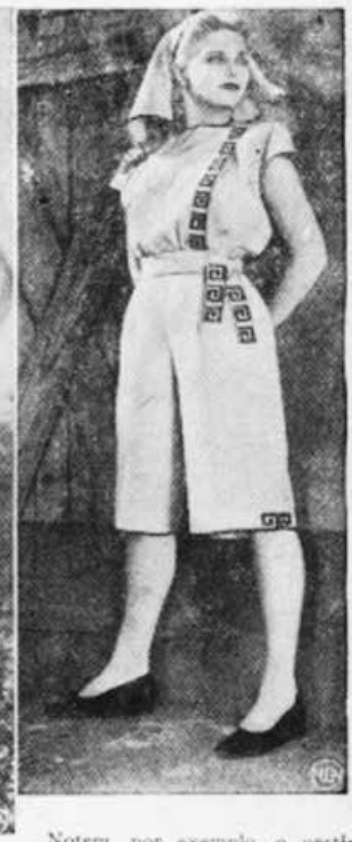

Noten, por exemplo, o vestiriaça de Fay Foster, coia lon. Os "slake" mereceram tan ém particular interézses entre od criadores californianos. Aqui te. mon erte, de linhas classicas, exe. a blusa fanisista, fuptets, a que a slesre o detrum das mavgas. combinando eom a gravata Colarinhe de pontas exageradas O terceiro modelo deats pisis a e especialmente derinado fictistas e como re ve, nem por Lerante e menos originai beje teil como entelis apetson uplicacio de gónto arteci traso de bea-visintunga - colit. Gletandorse o conjunto corn vis toncado, tambem erikinal e ele-

Figura 7 - Durante a direção de Elza Marzullo, o Suplemento Feminino divulgou diversas imagens relacionadas à produção da moda norte-americana. Fonte: $A$ Cigarra, novembro de 1945, p. 83. Acervo: Apesp. 
A estrutura do suplemento foi razoavelmente preservada até o primeiro semestre de 1947. É importante mencionar que, a partir desse ano, as tiragens e a lista de colaboradores (repórteres, artistas, cronistas) passaram a ser divulgados pela revista ${ }^{5}$. Dessa forma, sabemos, por exemplo, que todas as edições publicadas em 1947 e disponiveis no acervo digitalizado do Arquivo Público do Estado de São Paulo apresentaram uma tiragem igual ou superior a 100 mil exemplares, número muito considerável para a época.

Em 1946, Alceu Penna partiu rumo à sua primeira viagem para a Europa. Novamente, então, firmara um compromisso com a revista $O$ Cruzeiro, responsabilizando-se pelas encomendas internacionais e pela coluna Garotas (JUNIOR, 2010). Estando no Velho Continente, em um momento recente ao término da Segunda Guerra, acompanhou de perto as marcas deixadas por esta e, em Paris, os resquícios do Governo de Vichy. Também na França, foi testemunha dos esforços relacionados à reconstrução do país e ao reflorescimento e "último suspiro" da alta-costura (LIPOVETSKY, 2009. De acordo com Junior, "Alceu se impressionou principalmente com um nome, Christian Dior (1905-1957), o estilista que devolveu o esplendor à moda de Paris e receitou o luxo como o maior antidepressivo das classes altas no pós-guerra" (JUNIOR, 2011, pp. 226-228).

Em 1947, de volta ao Brasil, Alceu ilustrou o livro Detalhes de elegância e beleza, escrito por Elza Marzullo e publicado em dezembro de 1948 pela editora Cruzeiro S.A. Funcionando como uma espécie de manual feminino os principais assuntos abordados pelo livro são: comportamento, proporções ideais para o corpo feminino, maquiagem, penteados e acessórios, entre outros -, os desenhos do artista ajudavam o leitor a compreender melhor os conteúdos propostos pela autora.

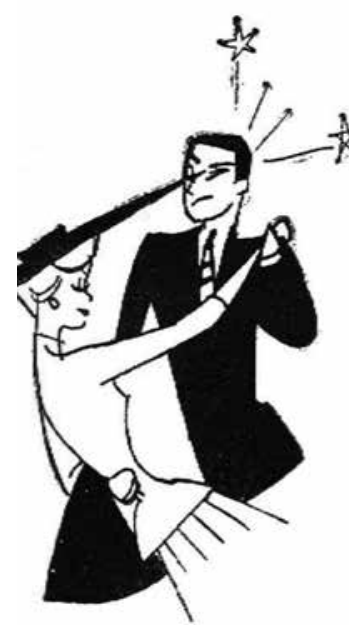

Figura 24

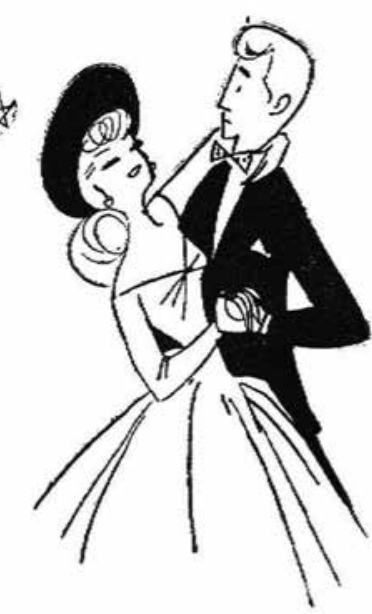

Figura 25

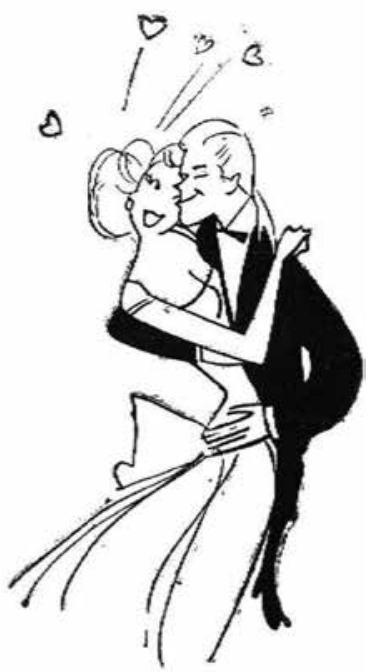

Figura 26

Figura 8 - "Evite chapéus, bolsas, etc., que chamam a atenção e incomodam, prejudicando a dança (Figura 24). Não se pendure no cavalheiro, agarrando-lhe o pescoço (Figura 25). Não assuma atitudes muito íntimas (Figura 26)." Fonte: MARZULLO, 1948, p. 35.

Ainda sobre as ilustrações do livro, é quase impossivel não as relacionar à experiência estrangeira vivenciada pelo artista - naquele momento ainda muito recente. Mesmo quando expressavam gestos e ações não compativeis com as normas da elegância (Figura 8), suas modelos contavam com todo o glamour da alta-costura ${ }^{6}$. No exemplo exposto, a primeira figura feminina (à esquerda) foi caracterizada com um traje que remete ao tailleur Bar, principal símbolo do 
New Look. Ao construir a imagem, Alceu teve o cuidado de acrescentar detaIhes que sugerissem as principais caracteristicas da toilette: na saia, os traços perpendiculares ao cós davam a ideia de pregas; já o casaquinho - que acompanhava as linhas do corpo e, abaixo da cintura, moldava-se perfeitamente ao volume da saia - era responsável por marcar a cintura da figura feminina, comprimindo-a. Lembrando a famosa fotografia de Willy Maywald, a modelo criada pelo mineiro utiliza um chapéu como principal acessório. A cor preta e o exagero da forma criam um efeito de destaque, que evoca atenção para 0 item, o qual, no contexto do livro, é o responsável pela situação deselegante, que incomoda o cavalheiro durante a dança.

Por meio dos desenhos presentes no livro e em outros trabalhos, pode-se dizer que Penna foi um dos grandes responsáveis, no Brasil, pela criação de determinado imaginário visual: aquele que remete ao fim da Segunda Guerra, à recuperação europeia, à alta-costura, ao New Look. A imagem a seguir, reprodução de duas páginas da seção de figurinos, expressa o momento em que Alceu privilegiou as produções da alta-costura francesa, apresentando-as, por meio de seus elegantes traços, aos leitores das revistas de Chatô. De acordo com Mara Rúbia de Sant'Anna: "Penna, ao publicar suas notas, opiniões e conselhos de elegância se constituía numa autoridade e o que afirmava se tornava lei; ele expressava um consenso geral da elite carioca que se fazia fascinada por Paris e todas as suas promessas de elegância, requinte e distinção" (2014, p. 26). A silhueta esbelta e alongada das figuras femininas era coberta por peças sofisticadamente traçadas. Como exímio ilustrador de moda, Alceu conseguiu transmitir aos leitores uma série de impressões relacionadas ao caimento, à costura, ao volume, ao movimento e à estampa de cada peça publicada.

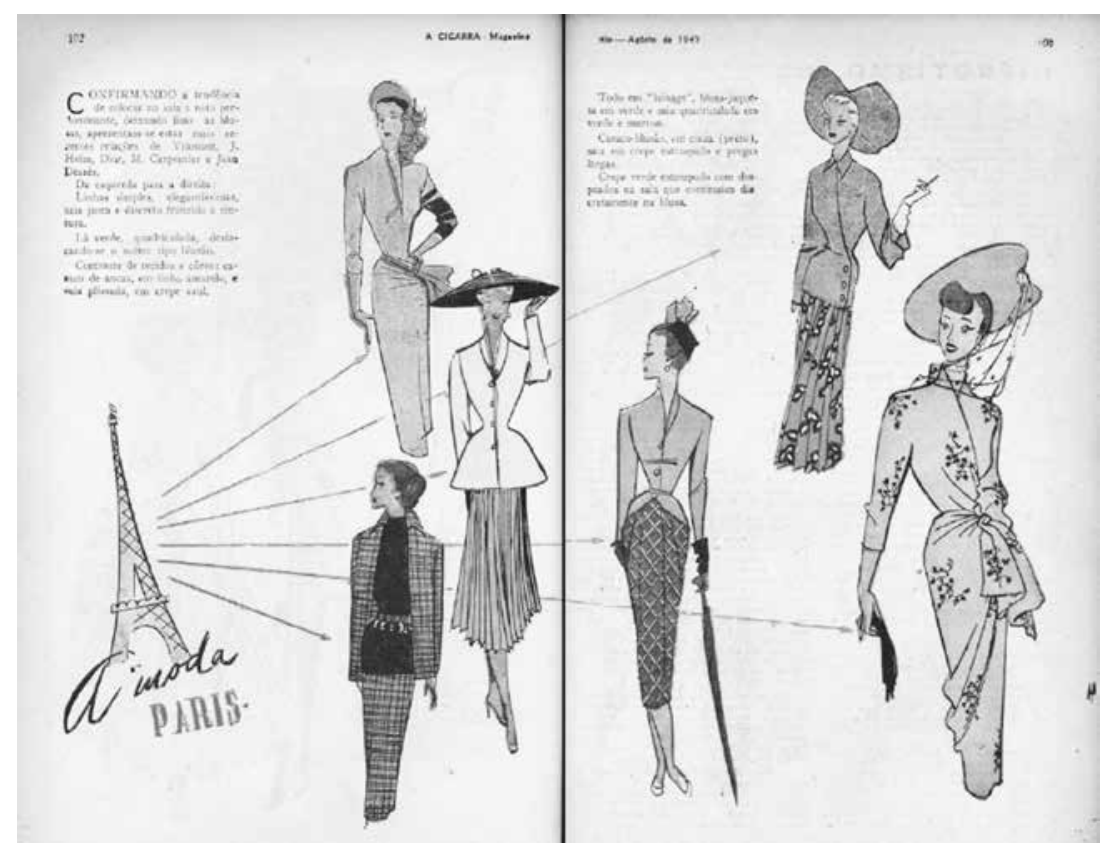

Figura 9 - Seção de figurinos, por Alceu Penna. Fonte: A Cigarra, agosto de 1947, pp. 102-103. Acervo: Apesp.

Na Figura 9, podemos observar reproduções das criações de Vramant, Jacques Heim, Dior, Carpentier e Dessés. Além de informar aos leitores a autoria de cada toilette reproduzida na seção, Alceu costumava realizar uma breve descrição das peças, comentando sobre a linha da silhueta, o tecido utilizado e 
as cores preponderantes. Ao apresentar peças inspiradas na alta-costura, 0 artista tinha como preocupação a adaptação daqueles modelos europeizados aos corpos das brasileiras: "Espero que dentro disso tudo elas consigam tirar algum partido, isto é, alguma coisa que fique bem para elas" - escreveu em carta a Accioly Netto (JUNIOR, 2011, p. 237). Essas pequenas adaptações - algumas vezes relacionadas ao tipo físico, outras mais ligadas às questões culturais (Carnaval) e políticas (Estado Novo, Política da Boa Vizinhança etc.) - foram fundamentais para o desenvolvimento de uma identidade nacional própria em termos de moda.

Das maisons até chegar ao corpo da brasileira, a moda passava por um inevitável processo de adaptações e reinterpretações. Mas ninguém, no Brasil de então, ousava ainda assumir a condição de criador! A moda vinha de Paris e ponto final; isso ninguém discutia. Mas, de cópia em cópia, mudando aqui e ali, costureiras, alfaiates e desenhistas deglutiam influências e, de algum modo, começavam a engendrar alguma identidade própria. (BRAGA; PRAD0, 2011, p. 138)

\section{A Cigarra Feminina}

Além da análise imagética e textual da fonte - 0 suplemento de $A$ Cigarra, chamado de $A$ Cigarra Feminina -, foram analisados alguns documentos relacionados aos trabalhos de Helena Ferraz de Abreu, especialmente aqueles produzidos para a revista. Estes, como o próprio projeto do suplemento e alguns recortes de jornais, foram essenciais à pesquisa, já que preencheram algumas importantes lacunas e apontaram a relevância do trabalho conjunto desenvolvido por Alceu, Helena e Elza. A compreensão da vida e da trajetória profissional da jornalista, que frequentemente assinava com o pseudônimo masculino Álvaro Armando, possibilitou outra leitura de seus textos, aproximando-os de uma proposta mais transgressora, ainda que tímida, do que normativa.

Praticamente todo o projeto do novo suplemento direcionado às leitoras de A Cigarra foi elaborado por Helena Ferraz de Abreu. Em carta a Lili (possivelmente Amélia Whitaker ${ }^{7}$ ), a jornalista comentou suas ideias para cada seção e, ao final, desenvolveu um parágrafo relacionado ao possivel título do caderno: "O título ELAS (que infelizmente não é original, os franceses têm uma revista "ELLE") é o que me parece mais sugestivo e menos pretencioso [sic]" (s.d., acervo pessoal).

Comparado ao projeto inicial, o primeiro número de $A$ Cigarra Feminina, publicado em junho de 1948, apresentou poucas alterações. Na capa, uma moldura cor-de-rosa, uma crônica escrita pela própria Helena (diretora) e a lista dos colaboradores: Alceu Penna, Armando Moura, Beatriz dos Reis CarvaIho, Elza Marzullo, Enrico Bianco, G. de Setúbal, Luiz Edmundo, Maria Helena, Maria Luiza, Prof. Mario Lima, Milton D'Ávilla, Jerônimo Ribeiro, J. Moura, Orlando Mattos, Dr. Silveira Sampaio, Stella e Tia Marta. Em seguida, a seção Mocinha, assinada por Tia Marta e ilustrada por Moura. Depois, Espelho Mágico, que, mais tarde, ficou conhecida como Elegância e Beleza, de Elza Marzullo. Três páginas foram exclusivamente reservadas aos figurinos de Alceu. 0 restante do grande suplemento era composto por seções relacionadas aos cuidados com a aparência pessoal e com o ambiente doméstico, poesias, um conto ilustrado, um teste chamado Eles e elas, receitas culinárias, segmentos que privilegiavam a participação das leitoras etc.

Em entrevista ao jornal Diário da Noite, Helena Ferraz comentou sobre o lançamento do novo suplemento feminino, dando ênfase, conforme mencio- 
nado anteriormente, às colaborações de Penna e Marzullo. Além de apresentar brevemente o programa do caderno, a diretora destacou que não teria caráter feminista, e sim feminino: "A política é esta: nada de "contra". A mulher pode concorrer para um mundo melhor, se ela começar tornando melhor o mundo de sua casa".

Elza Marzullo continuou com os trabalhos relacionados aos conselhos de beleza, elegância e comportamento. Alceu, como no Suplemento Feminino, permaneceu responsável pelas ilustrações, transformando os conselhos de Elza em imagens coloridas. A nova seção também investiu nas séries de exercícios para o corpo.

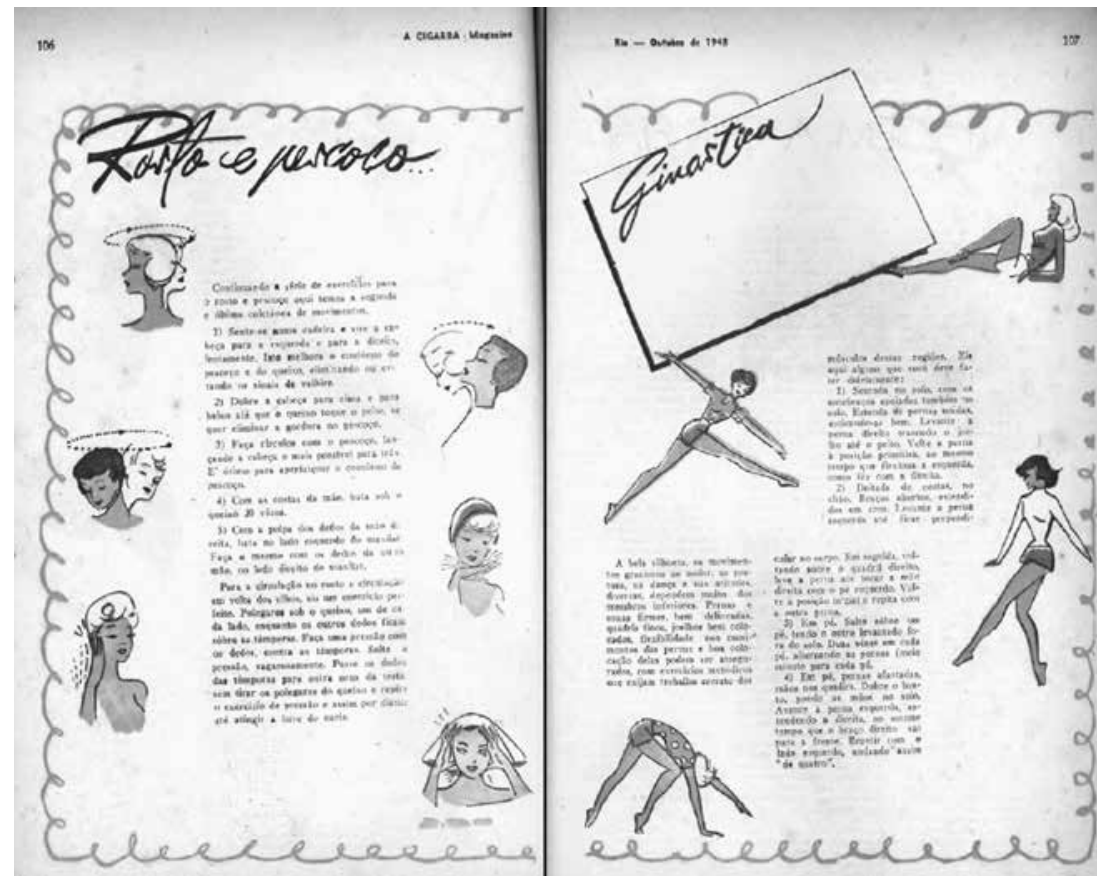

Figura 10 - Seção assinada por Marzullo e ilustrada por Alceu. Fonte: A Cigarra, outubro de 1948, pp. 106-107. Acervo: Apesp.

Nas décadas de 1940 e 1950, a conquista, quando associada ao casamento, era uma das principais preocupações femininas ou deveria ser, de acordo com os diferentes instrumentos normativos. A partir de recortes (1945-1964) da revista Jornal das Moças, Carla B. Pinsky observou que, apesar das mudanças sociais ocorridas ao longo do tempo, o matrimônio e a maternidade continuavam a ser "o destino das mocinhas de família" (1996, p. 60). Além de investir nas dicas sobre comportamento, a boa aparência era vendida na imprensa como uma

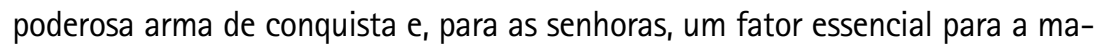
nutenção do casamento - afinal de contas, todos os infortúnios da vida conjugal eram atribuídos à esposa.

Na seção de ginástica (Figura 10), as figuras femininas desenhadas por Alceu trajavam roupas leves, de forma a transmitir aos leitores a impressão de movimentos livres e desenvoltos. Lá, elas não vestiam a "nova linha" francesa, não calçavam high heels, nem usavam penteados elaborados ou acessórios. As pernas, longilíneas e levemente torneadas, estavam expostas sem qualquer censura. Por meio dessa e de outras seções e colunas, Alceu Penna possibilitou, a partir de seus traços, um romper de olhares, antes acostumados a determinados tipos femininos. 
Diferentemente de Alceu e Elza, a experiente jornalista Helena Ferraz entrou para A Cigarra apenas no fim da década de 1940, justamente para dirigir o suplemento feminino - neste também era responsável por uma crônica (espécie de editorial) e pelos versinhos da coluna 0 marido de madame. Investigando sua produção textual para o suplemento, é difícil afirmar qual seria o seu posicionamento a respeito de questões relacionadas aos papéis femininos na sociedade brasileira. Os dois fragmentos a seguir, publicados em diferentes datas, exemplificam a postura de Helena.

\begin{abstract}
Não exponham os sentimentos, não bikinizem a alma. Os homens precisam imaginar dramas, desvendar mistérios, desvirginar emoções. Precisam principalmente: duvidar. Almas ventiladas, de janela aberta, sem poeiras de emoções, varridas de vento e brilhantes de sol, agradam mas não prendem. São os olhares velados que descem as cortinas e deixam à meia luz as almas da mulher. (A CIGARRA, fevereiro de 1950, p. 103 Acervo: Apesp)
\end{abstract}

De certa época para cá, veio a moda da alergia (...). A sra. Joyce Holdridge, de Los Angeles, entretanto, nem chegou a fazer testes. Descobriu a "olho nu" que toda vez que se aproximava do marido era acometida de eczema, uma erupção muito pouco fotogênica... 0 telegrama não chega à indiscrição de explicar se o fato ocorria só com o próprio marido (...). Como, porém, o próprio era o único divorciável, madame tratou logo de curar a coceira, rasgando a certidão de casamento, como o agente provocador. (A CIGARRA, janeiro de 1950, p. 103. Acervo: Apesp)

No primeiro excerto, tem-se a impressão de que Helena, seguindo as regras da imprensa feminina do período, colabora na divulgação de normativas relacionadas ao universo (um tanto quanto limitado) feminino. A construção de determinada imagem, pautada no mistério das máscaras, possibilitaria à mulher o êxito na conquista e, depois, a estabilidade do relacionamento conjugal. Tal preocupação, no entanto, não é percebida no segundo exemplo exposto. Neste, ao contrário, o casamento é apresentado como algo vulnerável, sem muita importância e passivel de humor.

Quando escreveu a carta a Lili, Helena Ferraz ainda não havia desenvolvido bem a ideia de uma coluna voltada aos jovens casais, presente nos planos da diretora para compor A Cigarra Feminina. Por isso, 0 marido de madame só foi lançada três meses após a divulgação do primeiro número do suplemento. Arnaldo Ferraz de Abreu disse que, depois de elaborar os versinhos, Helena encaminhava a historinha do mês a Alceu Penna, que, então, dava forma às personagens e às situações descritas. Na revista, a autoria do conteúdo textual era atribuída a Álvaro Armando, que, conforme já exposto, era um pseudônimo frequentemente utilizado pela jornalista. Alceu foi fundamental para o bom êxito de 0 marido de madame, uma vez que seus desenhos explicitavam de forma nítida e exagerada as principais caracteristicas das personagens e as situações relacionadas ao cotidiano do casal de classe média carioca, intensificando o efeito cômico dos versos.

Como em Garotas do Alceu, uma das principais marcas da HQ era o tom humoristico, incorporado aos versos e também às imagens. Entretanto, diferente da seção de 0 Cruzeiro, 0 marido de madame circulou como parte do Suplemento Feminino, e não em qualquer lugar da revista. Sobre o humor e seus possiveis significados e usos na imprensa, especialmente no caso da coluna Garotas, Gabriela Penna escreveu: "Ao mesmo tempo em que o humor possibilitava explorar questões incomuns na coluna 
e jamais discutidas em aberto, ele transformava aquelas ilustrações inanimadas em entidades mais próximas da realidade" (PENNA, 2010, p. 96).

Por meio do humor capaz de suavizar mensagens e da identidade masculina de seu pseudônimo, Helena Ferraz conseguiu falar aos públicos feminino e masculino, de forma a sugerir algumas contracondutas ${ }^{8}$, isto é, comportamentos e ações não condizentes com os ideais e as normativas do período. Se como cronista, sua postura não se revela de forma clara, as intenções de Álvaro Armando, observador irônico das relações humanas, são nítidas, levando o leitor a crer que Lolita, apesar das limitações que a permeiam, sempre consegue aquilo que deseja.

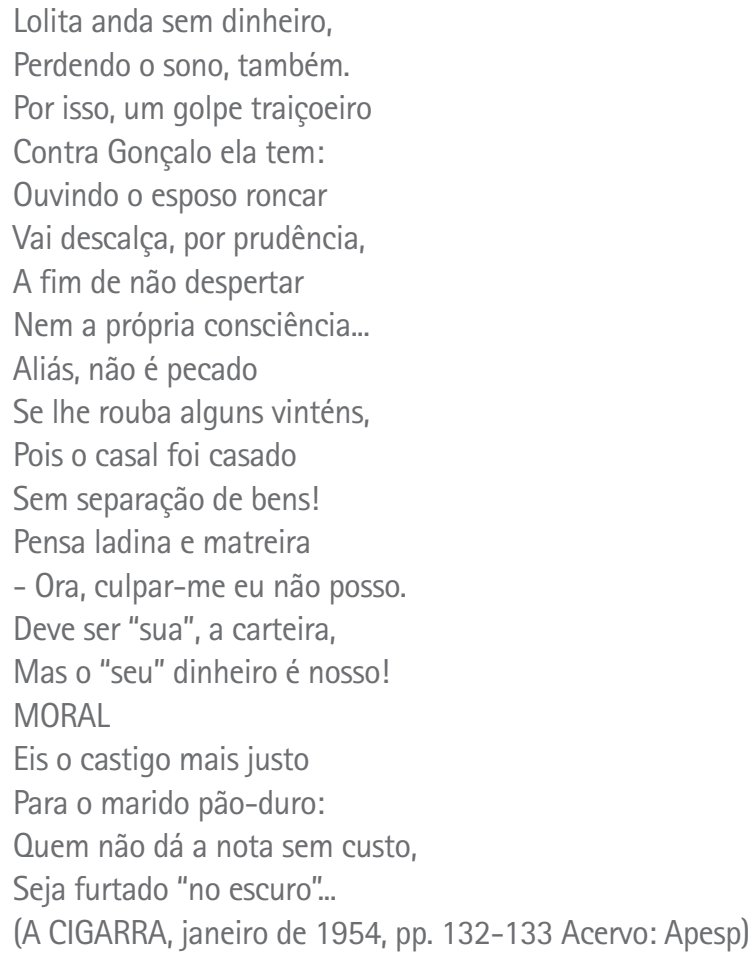

As ilustrações de Alceu conversavam com os versos da jornalista, confirmando as principais caracteristicas dos protagonistas. Seguindo os padrões de beleza do período, Lolita foi representada como uma mulher jovem, magra, alta, com cintura fina e marcada e cabelos curtos e escuros. Além dos traços que formavam a anatomia da personagem, havia aqueles responsáveis por Ihe cobrir o corpo, constituindo elegantes peças inspiradas na alta-costura. A silhueta esbelta de Lolita e a amplitude da vestimenta formavam um efeito gráfico capaz de captar (e centralizar) os olhares dos leitores. Assim, graças a tal recurso, a presença de Gonçalo parece sempre menor ou menos perceptiva, ainda mais quando desenhado próximo da madame.

As principais caracteristicas de Gonçalo foram descritas por Bonadio e Boaventura da seguinte forma:

(...) não era dotado de grande beleza: o rosto não seguia os padrões dos astros cinematográficos, como Montgomery Cliff ou Gregory Peck, atores que (...) arrebatavam suspiros das moças; era arredondado, com grandes bochechas, queixo pequeno e pescoço curto! As linhas um tanto desproporcionais conferiam um ar ingênuo e desengonçado ao personagem. (BONADIO; BOAVENTURA, 2013, p. 672) 

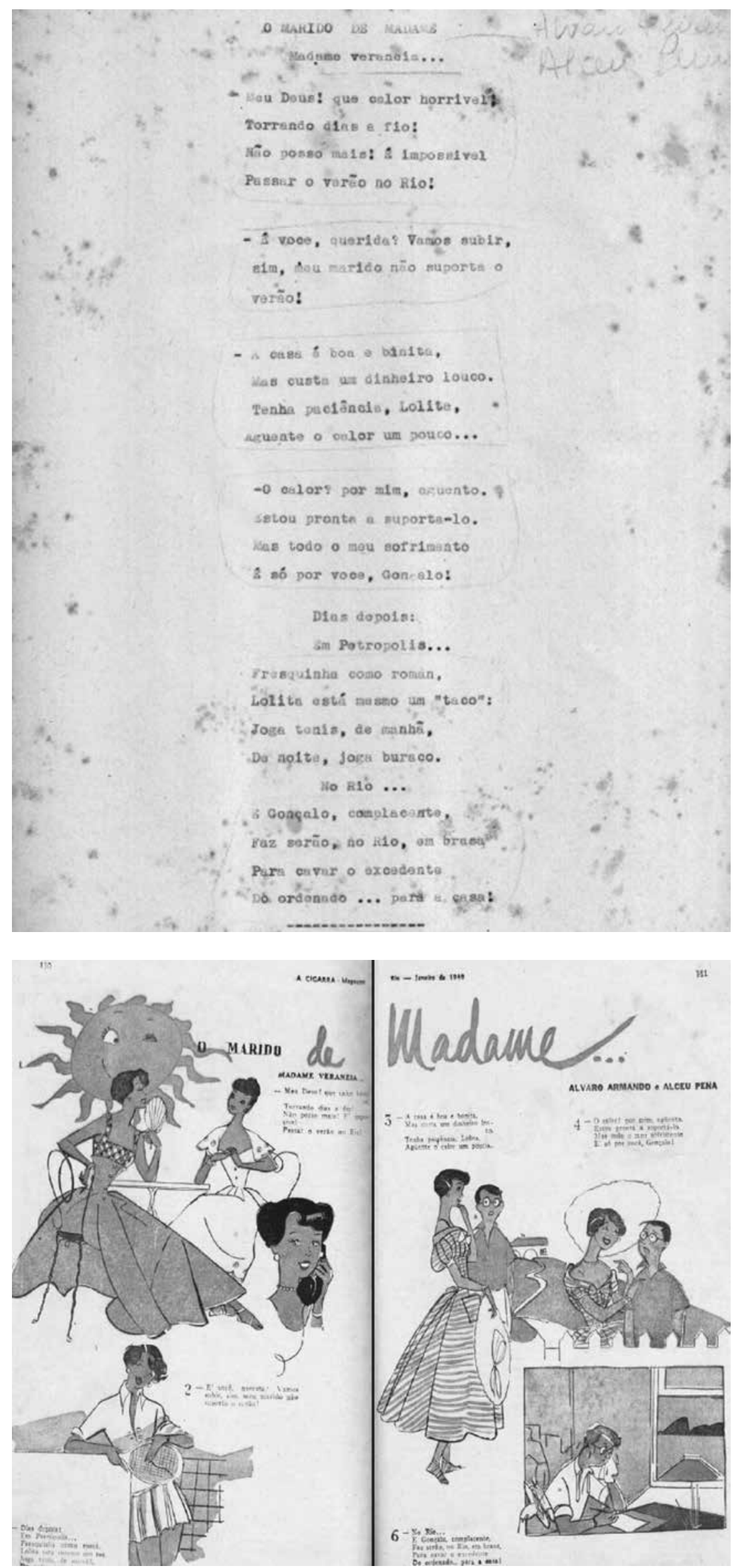

Figuras 11 e 12 - Texto original produzido por Helena Ferraz referente à historinha (Figura 12) publicada em janeiro de 1949, pp. 110-111. Fonte: Apesp e acervo pessoal respectivamente. 
Assim como quando desenhou a coluna Garotas, Alceu construiu personagens e situações alternativas àquelas propostas, muitas vezes, pela própria imprensa do periodo. Pinsky observou que, na imprensa, as representações do poder feminino poderiam aparecer de duas maneiras: uma considerada ideal e outra um exemplo a não ser seguido pelas leitoras:

\footnotetext{
Há muitos exemplos em Jornal das Moças de imagens femininas positivas, elogiadas e reforçadas, ligadas às figuras da esposa e da mãe: a fada, a santa e a rainha do lar. Elas se contrapõem às imagens da inconsequente, sonhadora ou queixosa e correspondem a poderes encobertos exercidos pelas mulheres sobre a felicidade da família, o bom andamento doméstico e o potencial e as decisões do marido. (BASSANEZI, 1996, p. 326)
}

A ideia que relaciona a mulher como principal detentora do poder no âmbito familiar foi questionada por Susan K. Besse. Segundo a autora, tal ideia - criada a partir de reivindicações femininas por maior igualdade perante aos homens -, além de ter acalmado os ânimos de uma parcela insatisfeita da sociedade, reforçou determinada estrutura familiar: a nuclear, composta por um casal heterossexual e pelos filhos. Apesar de possibilitar certa autonomia às mulheres, o casamento foi durante muito tempo encarado como destino ideal e único das "moças de família" (BESSE, 1999, p. 67).

Apesar de envolvida em um matrimônio heterossexual, de ser uma housewife e de, a todo instante, transparecer elegância e beleza, Lolita não corresponde totalmente aos papéis atribuidos à figura feminina do lar. Além do casal não possuir filhos (algo um tanto quanto incomum para a época), é Gonçalo quem, muitas vezes, assume as atividades domésticas. Assim, pode-se propor que 0 marido de madame, por meio de um humor atenuante, desafia a leitura de um passado associado a uma série de normativas que cercavam o universo familiar.

Enfim, a coluna Mocinha, também ilustrada por Alceu Penna ${ }^{9}$, encerra a apresentação dos principais trabalhos produzidos pelo artista mineiro para A Cigarra Feminina.

A partir da descrição do segmento Menina e moça, presente na carta de Helena Ferraz a Lili, subentende-se que a jornalista tinha em mente algo parecido com a Garotas do Alceu, de 0 Cruzeiro: "Tinha idéa de criar uns tipos bem "standard": Sônia, Verinha e Ana Maria e "trabalhar" com elas (...). Durante a vida movimentada dessas garotas (ilustradas por Alceu), abordariamos certos assuntos "tabu" - (Acervo pessoal). A coluna, com o título Mocinha, foi apresentada pela primeira vez ao público de $A$ Cigarra em junho de 1948.

Sobre a autoria do conteúdo escrito, não há qualquer evidência capaz de relacionar a personagem Tia Marta a um dos pseudônimos utilizados por Helena. Existe sim a hipótese de que a seção era comandada por Maria Luiza Castelo Branco, que também era uma das responsáveis pelas legendas da Garotas. Maria Luiza também foi uma das cronistas de $A$ Cigarra Feminina e continuou a escrever sobre assuntos femininos mesmo após a saída de Helena Ferraz da revista e o consequente término do suplemento, em meados de 1955. 


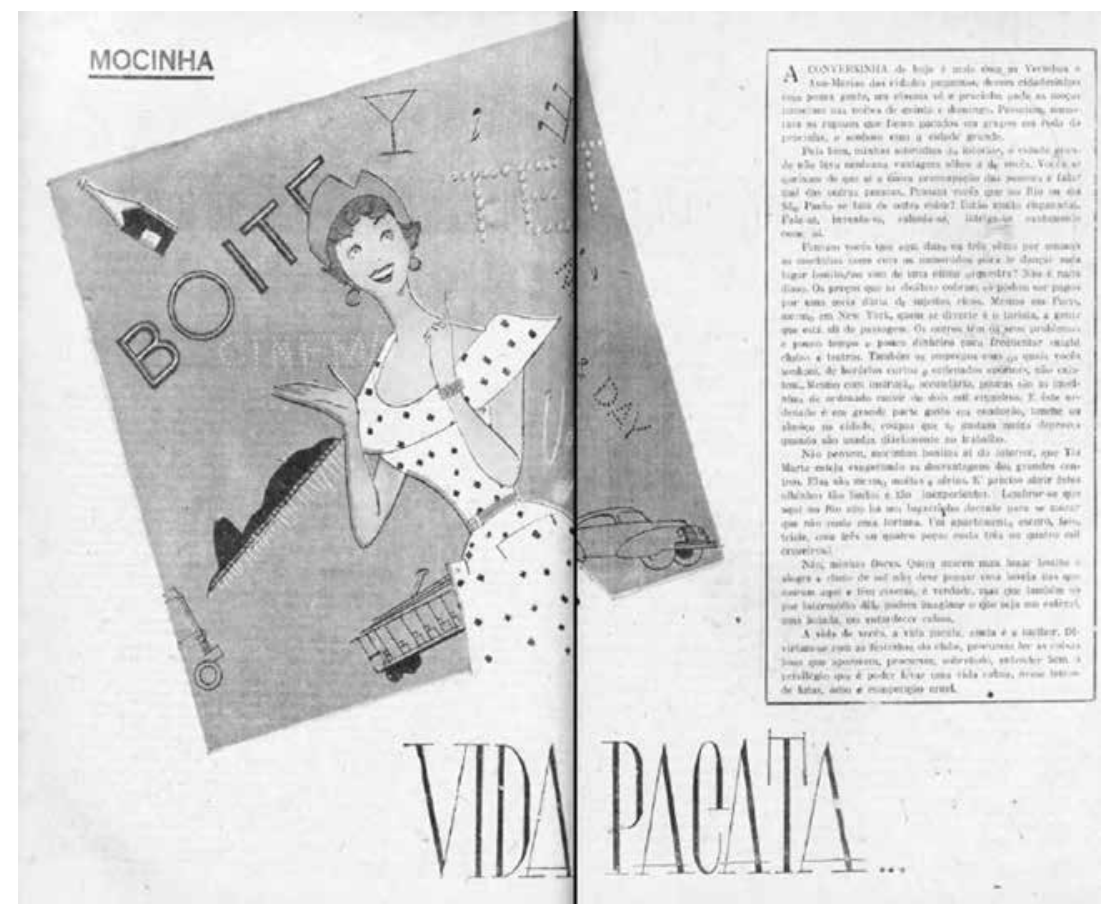

Figura 13 - Mocinha em Vida pacata. Fonte: A Cigarra, novembro de 1950, pp. 114-115. Acervo: Apesp.

Diferentemente de Lolita e das modelos estampadas na seção de figurinos, as sobrinhas de Marta foram construidas a partir de traços que remetiam à ideia de juventude, tal como as Garotas: rosto arredondado, olhos grandes e marcantes, poses descontraídas, vestimentas menos formais, cabelos compridos etc. Por sua vez, o conteúdo textual era frequentemente extenso, divergindo daquele formato presente em 0 marido de madame, por exemplo. Ainda que a intenção primeira de Helena Ferraz fosse a de dialogar com as mocinhas solteiras, "absolutamente sem o 'tom' conselheiral", os conteúdos transmitidos por Tia Marta apresentavam uma série de imperativos. Sua experiência de vida funcionava, assim, como principal instrumento na legitimação de seus conselhos.

E, querida, Ano Novo é mesmo tempo de boas resoluções. E na lista tia Marta sugere que você exclua as seguintes: a) não usar mais o maiô que deixa papai tão zangado; b) não pirraçar com tanta frequência seus primos pequenos; c) ir à missa vestida de missa e não "passar" pela missa já pronta para outro programa que inclui decote; d) não ler os livros que estão no alto da estante. (A CIGARRA, ano XXXVI, n. 1, janeiro de 1955, pp. 132-3. Acervo: Apesp)

Com relação às escolhas artísticas que compõem a imagem, Verinha (Figura 14) poderia muito bem se passar por qualquer outra garota de Alceu. Contudo, é por meio dos cenários ${ }^{10}$, de alguns gestos $\mathrm{e}$, principalmente, dos conteúdos textuais que conseguimos identificar as particularidades que separam Mocinha de Garotas do Alceu. Diferentemente da famosa coluna de 0 Cruzeiro, a linguagem utilizada em Mocinha era mais séria, permeada por conselhos, lições de moral e repreensões. 0 humor, tão presente em 0 marido de madame e em Garotas, não fez parte do recurso linguístico utilizado por Tia Marta. Assim, todas as possibilidades relacionadas às contracondutas ficaram restritas às ilustrações. Alceu Penna, antenado, talentoso e ousado, parece ter aproveitado os recursos oferecidos pela linguagem visual, de modo a criar lindas e, por vezes, provocantes Verinhas e Anas Marias. 


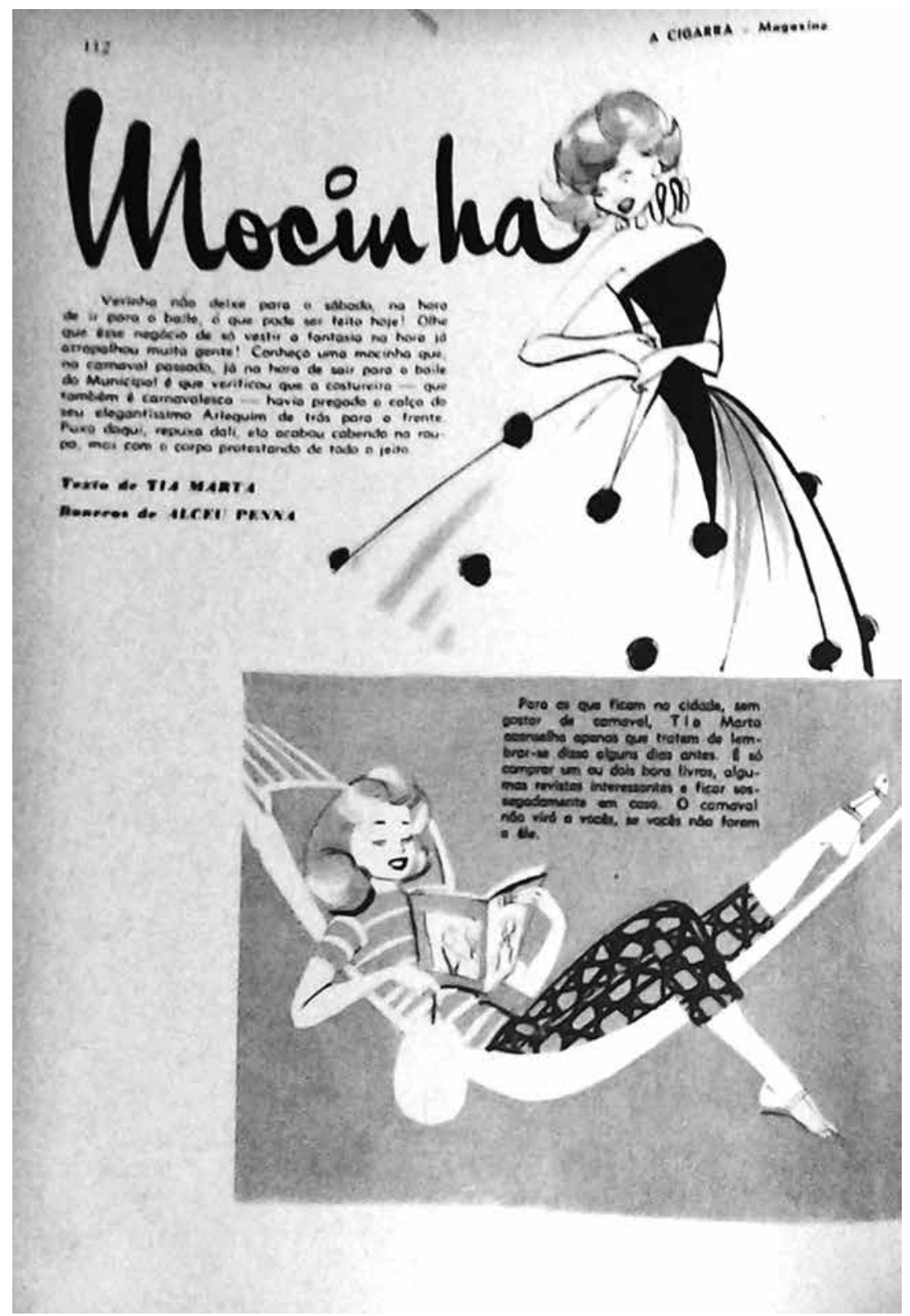

Figura 14 - Depois que a seção 0 marido de madame deixou de circular, os textos da coluna Mocinha foram reduzidos e inseridos em balões, imitando uma HO. Fonte: $A$ Cigarra, setembro de 1955, pp. 110-111. Acervo: Apesp.

Comparada à Garotas, a coluna em questão circulou de maneira breve, deixando as páginas de A Cigarra em meados de 1957, cerca de dois anos após 0 término de $A$ Cigarra Feminina. Isso possivelmente significa que os conselhos e valores transmitidos por Tia Marta tornaram-se old style, isto é, velhos demais para uma nova e particular geraçãon ${ }^{11}$.

\section{Considerações finais}

Alceu de Paula Penna nasceu em data próxima (1915) ao lançamento de ACigarra (1914). Anos mais tarde, no início da década de 1930, mudou-se de Curvelo, sua cidade natal, para o Rio de Janeiro, então capital do país, lugar das possibili- 
dades relacionadas às artes, à imprensa e às celebrações sociais. Concomitante ao andamento do curso de Arquitetura, o jovem mineiro iniciou os trabalhos como ilustrador e figurinista. Nessa mesma época, A Cigarra foi comprada por Assis Chateaubriand, sendo incorporada ao conglomerado de empresas de mídia do empresário. Como parte dos Diários Associados, a revista passou por uma série de transformações, sendo então deixada nas mãos dos mesmos colaboradores do famoso semanário ilustrado 0 Cruzeiro. Alceu Penna tornou-se ilustrador de ambas as publicações.

A grande tiragem de 0 Cruzeiro - que, na década de 1950, chegava a 500 mil exemplares por edição -, além de sua periodicidade (semanal), podem ter diminuído a importância, no passado e no presente, de $A$ Cigarra. Talvez por isso, a coluna Garotas do Alceu seja mais lembrada que Mocinha ou 0 marido de madame. Além do mais, o número de pesquisas que utiliza 0 Cruzeiro como fonte e objeto de análise é visivelmente superior àquele relacionado à revista fundada por Gelásio Pimenta.

De qualquer forma, enquanto veículo impresso de comunicação, a importância de A Cigarra pode ser constatada por seu tempo de circulação (aproximadamente meio século), sua tiragem (cerca de 100 mil exemplares no fim da década de 1940) e da quantidade de páginas por publicação (mais de 150, na primeira metade da década de 1950). Assim, considerando esses dados, pode-se deduzir a pertinência do mensário na divulgação de prerrogativas e ideias e na construção de caracteristicas culturais e sociais em determinados períodos. É por isso que diversos fragmentos de A Cigarra foram essenciais em algumas pesquisas sobre mulheres no Brasil. Exemplos são os trabalhos de Susan K. Besse (1999), Dulcilia Buitoni (2009) e Vânia de Carvalho (2008). Apesar disso, tais investigações estiveram focadas em um recorte temporal que abrange a primeira fase da revista, anterior à compra realizada por Chateaubriand. É raro encontrar trabalhos que tratem ou mencionem a incorporação da publicação aos Diários Associados, ou que atentem ao período posterior à década de 1930. Nesse sentido, algumas pesquisas desenvolvidas por Maria Claudia Bonadio - como o artigo já citado, sobre as representações visuais do casamento e da juventude - são exceções.

Alceu transformou a seção feminina da revista adquirida por Chatô: impulsionou o gosto pela moda, tratando-a como negócio sério a partir de seus croquis e de suas legendas explicativas; exemplificou, visualmente, os conteúdos divulgados por Elza Marzullo e Helena Ferraz de Abreu; propagou novas e ousadas imagens, rapidamente incorporadas pelas leitoras mais jovens. E quando teve que dividir o trabalho com alguém mais conservador - atividade constante em sua trajetória -, nas entrelinhas (ou nos entretraços), foi capaz de propor alternativas ao público: o conteúdo escrito até poderia ir ao encontro das prerrogativas da época, mas as ilustrações chamavam a atenção e encantavam por seu caráter ousado e inovador.

Na segunda metade dos anos 1950, A Cigarra novamente enfrentou um processo de modificações gráficas e de conteúdo. Em 1955, elementos da moda foram divulgados por intermédio dos desenhos de Alceu, como de costume, e também por uma série de fotografias; independentemente do recurso imagético utilizado, era o ilustrador figurinista quem elaborava os textos, relacionando-os às imagens expostas.

Comparadas as ilustrações feitas para a seção de figurinos de $A$ Cigarra Feminina, as criações de Alceu publicadas nos anos 1960 tinham as medidas, os perfis, as poses e, é claro, as roupas bastante divergentes. Inclusive, a porcentagem que cada desenho ocupa na página, além das dimensões dos corpos das modelos e das técnicas utilizadas na construção e no desenvol- 
vimento dos croquis foram visivelmente alteradas. Na imagem a seguir, por exemplo, as roupas aparecem em destaque, coloridas em azul, e se sobrepõem em relação às figuras femininas - que parecem estar ali simplesmente pela necessidade de vestir e apresentar o caimento de cada roupa proposta, de forma a potencializá-la. Ainda assim, tais figuras dizem muito a respeito da moda do período, não apenas pelos blusões e minissaias, peças ícones dos anos 1960, mas também pelos cabelos, penteados, acessórios e poses. De acordo com Bethan Morris,

as poses das ilustrações transformaram-se de recatadas e contidas para provocantes e dinâmicas. No entanto, o ilustrador de moda tornou-se menos importante para as revistas do que o fotógrafo, tanto que os fotógrafos e as modelos tornaram-se as celebridades do momento. (MORRIS, 2009, p. 146)

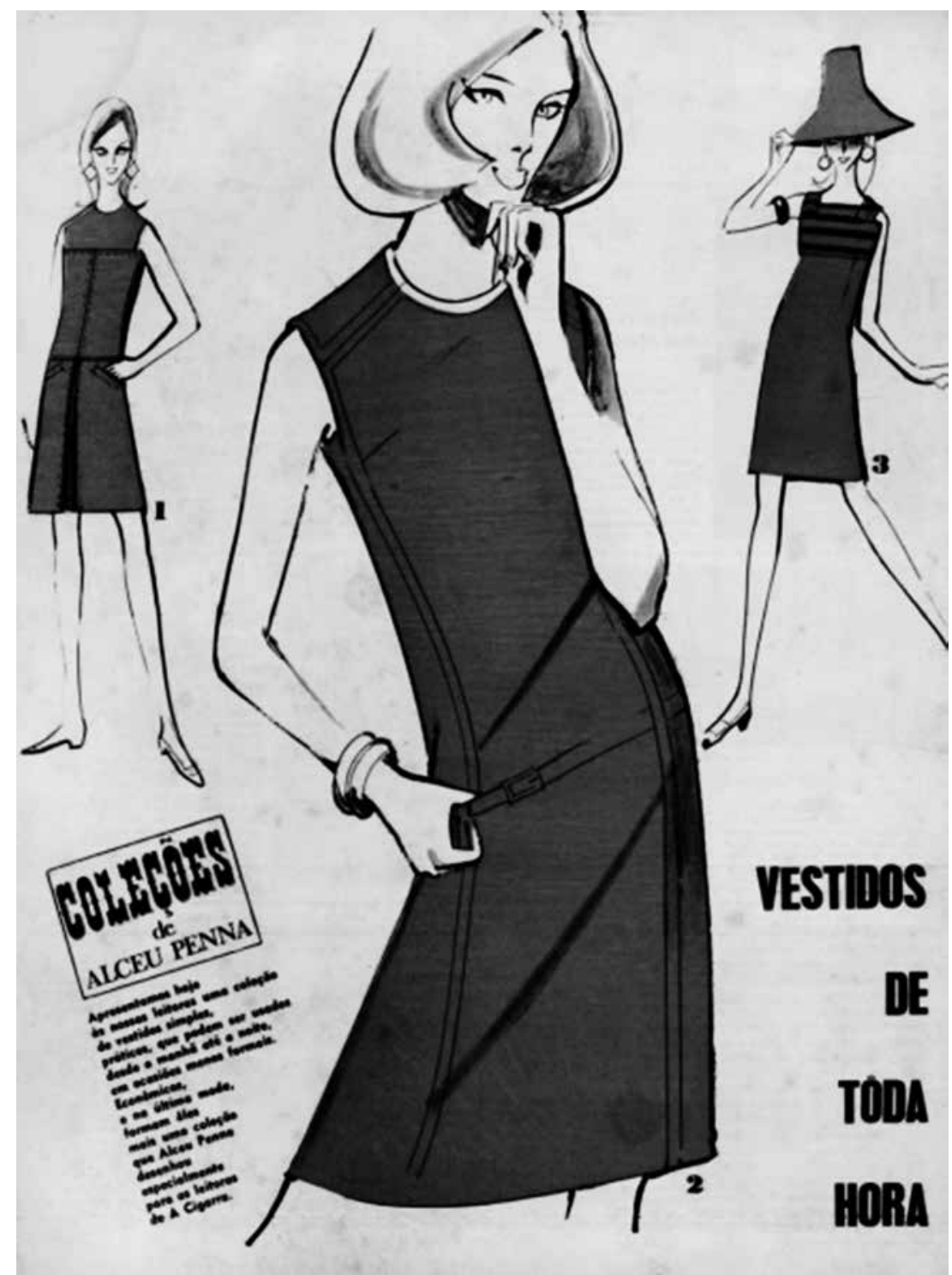




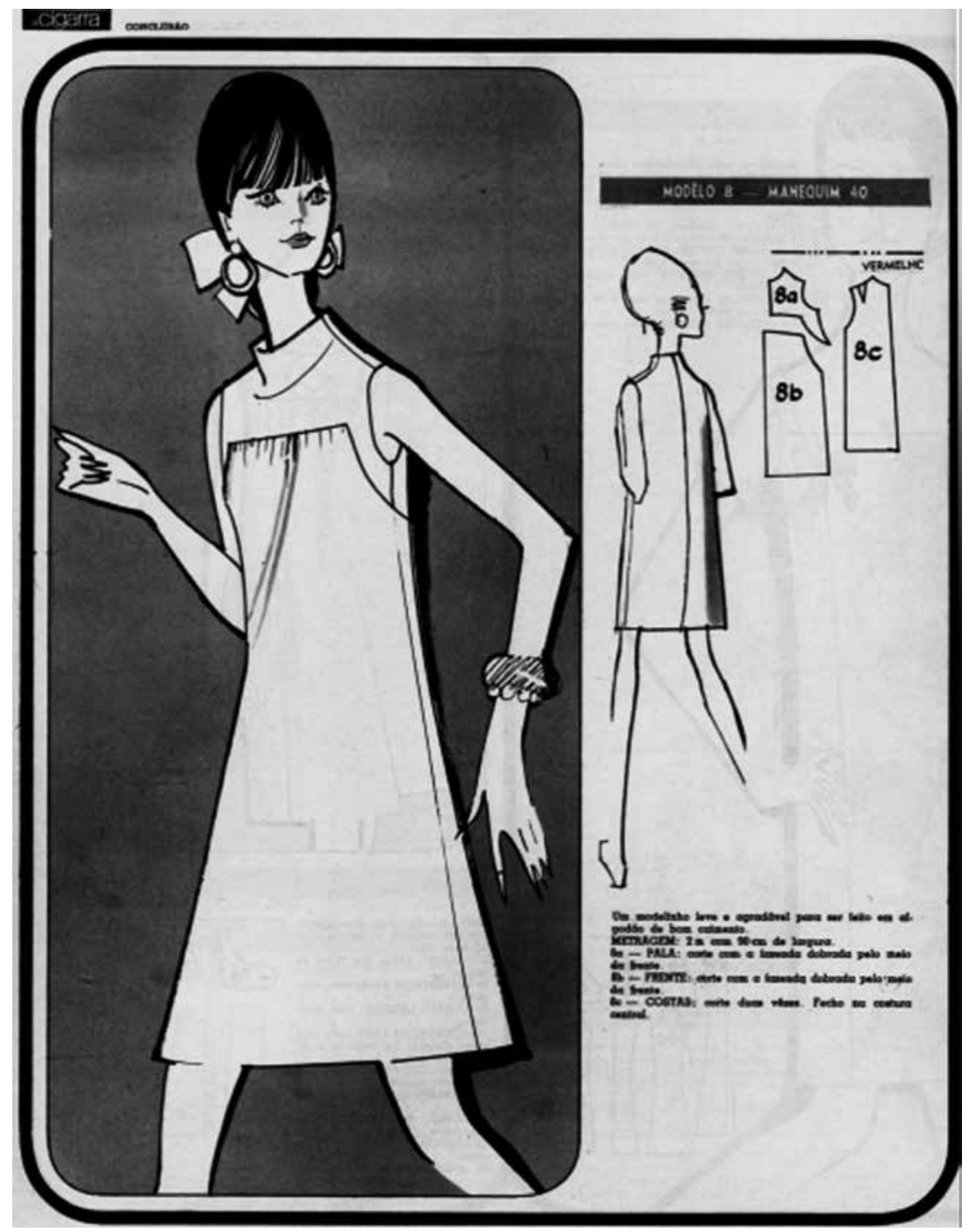

Figuras 15 e 16 - Coleções de Alceu e criações especiais de Alceu Penna, exclusivas de A Cigarra. Fonte: A Cigarra, setembro de 1966, p. 86, e agosto de 1967, p. 67. Acervo: Apesp.

Alceu demonstrou tamanha versatilidade ao ilustrar diferentes projetos, das histórias em quadrinhos infantis aos moldes de peças publicadas em meados da década de 1960 (Figura 16). Nas revistas dos Diários Associados, e concomitante aos trabalhos como figurinista, teve a oportunidade de expressar seu gosto pela moda e suas aptidões, por isso, foi, durante anos, responsável pelas seções de figurinos de 0 Cruzeiro e de $A$ Cigarra. E mesmo quando a moda deixou de ser especialmente divulgada por meio das ilustrações, 0 artista mineiro continuou a criar figuras femininas vestidas com peças e poses da "última moda"12. Obsenvando os números de $A$ Cigarra publicados entre as décadas de 1940 e 1960, há de se pensar sobre a ligação envolvendo os trabalhos desenvolvidos por Alceu e uma possivel história do desenho de moda no Brasil - ainda que fosse atrelada a uma série de códigos e referências internacionais, vindos da Europa e dos Estados Unidos, principalmente.

Sendo um bem de consumo, as revistas optavam (e assim o fazem até hoje) pela publicação de assuntos do interesse da maior parte de seu público. Como uma revista de variedades altamente consumida por mulheres, A Cigarra sempre (ou quase sempre) investiu em segmentos voltados à moda (vestuário). Nesse sentido, Alceu Penna foi um grande achado, que, desde os primeiros traços, encantou pessoas, como o próprio Assis Chateaubriand. Considerado por A Cigarra como um dos maiores mestres da moda no Brasil, o artista criou e recriou maneiras de ver, consumir e incorporar, não apenas o "fenômeno efêmero" (a moda), mas, principalmente, as atitudes que, a partir do vestuário, constituem e transformam os sujeitos. 


\section{NOTAS}

[1] 0 presente artigo é resultado da pesquisa de mestrado Madames e mocinhas em revista: corpo, gênero e moda em A Cigarra (1940-1955), desenvolvida no PPPG em História da Unicamp com financiamento da Fapesp processo: 2013/05161-2.

${ }^{[2]}$ A Cigarra, ano I, n. 1, 6 de março de 1914. Acervo: Arquivo Público do Estado de São Paulo (Apesp).

${ }^{[3]}$ Um exemplo: o número publicado em agosto de 1937 tratou como Suplemento Feminino duas seções: Modas em Paris e Hollywood, alocada entre as páginas 109 e 124, e Caricaturas, distribuida de forma aleatória pela revista. As caricaturas eram, na maioria das vezes, assinadas por Abner Dean (1910-1982), cartunista norteamericano que trabalhou na Esquire Magazine, uma revista de interesse masculino, lançada em 1933. A Cigarra, ano XXIII, n. 41, agosto de 1937. Acervo: Apesp.

${ }^{[4]}$ Mesmo distante, Alceu continuou a enviar à redação de 0 Cruzeiro uma série de trabalhos relacionados à coluna Garotas. Neste caso, além de ilustrar, ele também foi responsável pelas legendas. Segundo Maria Claudia Bonadio, "(...) os textos (...) passam a ser narrados em $1^{\text {a }}$ pessoa e sugerem que Alceu (...) atuava como um voyeur, um observador indiscreto que espia e relata ao público as situaç̃es vividas pelas Garotas na terra do Tio Sam (...)" (BONADI0, s.d., p. 7). Pode-se concluir, então, que o ilustrador foi um dos responsáveis, no Brasil da "Boa Vizinhança", pela disseminação de costumes norte-americanos.

${ }^{[5]}$ No periodo que compreende os meses finais de 1945 até meados de 1947, não há qualquer indício que aponte a participação de Alceu no Suplemento Feminino, apesar de seu nome aparecer na lista de colaboradores do departamento artístico de A Cigarra. A partir do segundo semestre de 1947, as ilustrações do mineiro voltaram a estampar as páginas da seção, em um formato muito semelhante àquele que vigoraria em A Cigarra Feminina, título do novo suplemento dirigido ao público feminino e lançado em 1948.

${ }^{[6]}$ Em nota, ainda no prefácio, Elza Marzullo expôs o seguinte: "Era nossa intenção incluir neste livro o indispensável capitulo referente ao vestuário. Nele seriam estudados os efeitos dos detalhes nas várias partes do vestido, bem como os das cores, dos contrastes, das linhas, etc. aplicados aos diferentes tipos femininos. Dada a complexidade e relativa independência desse vasto assunto, julgamos ser de maior utilidade abordá-lo em livrinho à parte" (1948, p. 14). No entanto, não foram encontradas outras informações acerca da publicação do tal livrinho.

${ }^{[7]}$ Amélia Whitaker, a dona Lili, era casada com Leão Gondim de Oliveira, primo de Chateaubriand. De acordo com Accioly Netto, Gondim foi, durante muito tempo, o dono da bola em 0 Cruzeiro, isso porque era dono de $75 \%$ das ações da Empresa Gráfica. Amélia era filha de um banqueiro e pertencia à alta sociedade paulistana. Foi diretorapresidente das revistas dos Diários Associadose responsável por uma série de mudanças nas estruturas de alguns segmentos dos impressos. Ainda segundo Netto, "a influência de dona Lili foi também nefasta para as páginas de "As Garotas" (...). Seus diálogos, escritos inicialmente por Lyto (mais um pseudônimo meu) e depois por A. ladino, um jornalista de muito talento, primavam por um humor juvenil e agradável. Mas, por interferência de dona Lili, eles passaram a ser feitos pela inexperiente Lia Castelo Branco. E "As Garotas" passaram a falar só coisas chatas, sempre em tom de conselho" (1998, p. 82).

[8] Para o filósofo Michel Foucault, a contraconduta é uma luta contra os procedimentos postos em prática para conduzir os outros (2008, p. 266).

[9] Os primeiros números da seção Mocinha não foram ilustrados por Alceu Penna, e sim por Moura, do departamento artístico de A Cigarra. Infelizmente, não foram encontradas mais informações relacionadas à produção desse ilustrador.

${ }^{[10]}$ As Garotas eram frequentemente contextualizadas em ambientes de sociabilidade, como praias e clubes.

[11] De acordo com Maíra Zimmermann, "a liberdade comportamental que, aos poucos, seria introduzida socialmente pelos jovens comecaria a modificar as relações sociais calcadas na tradição familiar nuclear, em que o espaço privado era dedicado às mulheres, e o público, aos homens. As novas músicas, as roupas, enfim, os novos gostos difundidos pelos mais jovens causavam impacto na sociedade tradicional, onde havia uma clara divisão entre homens e mulheres (...)" (ZIMMERMANN, 2013, p. 49).

${ }^{[12]}$ De acordo com Bonadio,"a ampliação e a consequente segmentação do mercado de revistas trouxeram a necessidade da produção de editoriais de moda, abrindo espaço para o trabalho de fotógrafo de moda no Brasil. Nos anos 1960, alguns nomes despontaram no mercado. A começar por Otto Stupakoff, considerado o primeiro fotógrafo brasileiro especializado em moda e internacionalmente reconhecido" (2014, p. 187). 


\section{REFERÊNCIAS}

ARMANDO, Álvaro. Na berlinda. Rio de Janeiro: Civilização Brasileira S.A., 1947.

BASSANEZI, Carla. Virando as páginas, revendo as mulheres: revistas femininas e relações homemmulher, 1945-1964. Rio de Janeiro: Civilização Brasileira, 1996.

BESSE, Susan K. Modernizando a desigualdade: reestruturação da ideologia de gênero no Brasil, 1914-1940. São Paulo: Edusp, 1999.

BONADIO, Maria Claudia. Moda e publicidade no Brasil nos anos 1960. São Paulo: nVersos, 2014

BONADIO, Maria Claudia; BOAVENTURA, Thaís F. Alceu Penna e as representações gráficas do casamento e da juventude na revista A Cigarra (1947-1955). In: Diálogos, Vol. 17, No 2 (2013). Disponivel em: <http://www.dialogos.uem.br/index. php?journal=0jsctpage =articlectop $=$ view\&tpath $\% 5 B \% 5 D=726$ (tpath\%5B\%5D=pdf_581>. Acesso em: 15 jan. 2015.

BONADIO, Maria Claudia; GUIMARÃES, Maria Eduarda A. Alceu Penna e a construção de um estilo brasileiro: modas e figurinos. Horizontes Antropológicos, Porto Alegre, ano 16, n. 33, p. 145-175, jan./ jun. 2010.

BRAGA, João; PRADO, Luís. História da moda no Brasil: das influências às autorreferências: 2a . edição. São Paulo: Disal, 2011.

BUENO, Maria Lucia. Alta-costura e alta cultura. As revistas de luxo e a internacionalização da moda (1901-1930). In: MESOUITA, Cristiane; PRECIOSA, Rosane. Moda em ziguezague: interfaces e expansões. São Paulo: Estação das Letras e Cores, 2011.

BUITONI, Dulcilia Helena Schroeder. Mulher de papel: a representação da mulher na imprensa feminina brasileira. 2a edição. São Paulo, Summus, 2009.

CARVALHO, Luiz M. Cobras criadas: David Nasser e O Cruzeiro. São Paulo: Senac, 2001.

CASTRO, Ruy. Carmen: uma biografia. São Paulo: Companhia das Letras, 2005.

CRUZ, Heloisa F. (org.). São Paulo em revista: catálogo de publicações da imprensa cultural e de variedades paulistana 1870-1930. São Paulo: Arquivo do Estado, 1997.

FOUCAULT, Michel (trad. De Eduardo Brandão). Segurança, território e população. São Paulo: Martins Fontes, 2008.

HAYE, Amy de la; MENDES, Valerie. A moda do século XX. São Paulo: Martins Fontes, 2003.

JUNIOR, Gonçalo. A guerra dos gibis: a formação do mercado editorial brasileiro e a censura aos quadrinhos, 1933-64. São Paulo: Companhia das Letras, 2004.

. Alceu Penna e as garotas do Brasil. Moda e Imprensa-1933/1980. São Paulo: CLUQ, 2004.

LIPOVETSKY, Gilles. O império do efêmero: a moda e seu destino nas sociedades modernas. São Paulo: Companhia das Letras, 2009.

LOPES, Antônio Herculano; PESAVENTO, Sandra Jatahy; VELLOSO, Monica Pimenta (Orgs.). História e linguagens: texto, imagem, oralidade e representações. Rio de Janeiro: 7Letras, 2006.

MARTINS, Ana Luiza. Revistas em revista: imprensa e práticas culturais em tempos de República, São Paulo (1890-1922). São Paulo: Edusp, 2001.

MARZULLO, Elza. Detalhes de elegância e beleza. Rio de Janeiro: 0 Cruzeiro, 1948.

MORAIS, Fernando. Chatô: o rei do Brasil, a vida de Assis Chateaubriand. São Paulo: Companhia das Letras, 1994.

MORRIS, Bethan. Fashion Illustrator: manual do ilustrador de moda: 2a edição. São Paulo: Cosac Naify, 2009.

NETTO, Accioly. Império de papel. Os bastidores de O Cruzeiro. Porto Alegre: Sulina, 1998.

O'DONNELL, Julia. A invenção de Copacabana: culturas urbanas e estilos de vida no Rio de Janeiro (1890-1940). Zahar, 2013.

PENNA, Gabriela O. Vamos garotas! Alceu Penna: moda, corpo e emancipação feminina (1938-1957). São Paulo: Annablume, Fapesp, 2010. 
PERROT, Michelle. Mulheres públicas. São Paulo: Fundação editora da UNESP, 1998.

PINSKY, Carla B.; PEDRO, Joana Maria (orgs). Nova história das mulheres no Brasil. São Paulo: Contexto, 2012.

ZIMMERMANN, Maíra. Jovem Guarda: moda, música e juventude. São Paulo: Estação das Letras e Cores, 2013

\section{FONTES ESCRITAS}

A Cigarra (1914-1967). Acervo: Arquivo Público do Estado de São Paulo (Apesp).

AManhã, 11 de fevereiro de 1943. Acervo: Fundação Biblioteca Nacional.

OCruzeiro, 6 de março de 1954. Acervo pessoal.

O Globo, 13 de dezembro de 1979. Acervo: O Globo.

O Jornal, 14 de abril de 1934. Acervo: Fundação Biblioteca Nacional.

Demais documentos: projeto de $A$ Cigarra Feminina, cartas, originais de crônicas e da seção 0 marido de madame. Acervo pessoal.

\section{FONTES ORAIS}

Arnaldo Ferraz de Abreu. Rio de Janeiro, 20 de março de 2014.

Celina de Farias. Rio de Janeiro, 19 de março de 2014. 